\title{
Institutional barriers and job creation in Central and Eastern Europe
}

\author{
Jesús Crespo Cuaresma ${ }^{1,2,3,4}$, Harald Oberhofer ${ }^{5,6^{*}}$ and Gallina A Vincelette ${ }^{7}$
}

\author{
* Correspondence: \\ harald.oberhofer@sbg.ac.at \\ ${ }^{5}$ University of Salzburg, Salzburg, \\ Austria \\ ${ }^{6}$ Austrian Center for Labor \\ Economics and the Analysis of the \\ Welfare State, Linz, Austria \\ Full list of author information is \\ available at the end of the article
}

\begin{abstract}
Using information from the Amadeus dataset and the Business Environment and Enterprise Performance Survey, we provide an empirical investigation of the industry and firm-specific determinants of the intensive margin (i.e., within existing firms) job creation process in eleven Central and Eastern European economies during the period 2002-2009. Our results indicate that during the years prior to the global financial crisis, traditional industries were crucial for the net intensive margin creation of jobs in the region but, by contrast, services firms were less vulnerable to the economic downturn. At the firm level, small and young already existing firms and subsidiaries of multinational corporate groups tended to register the highest employment growth rates. The empirical results also indicate that more productive surviving firms tended to be less vulnerable to the economic downturns in terms of employment change. The perceived quality of the business climate by enterprises of the region is robustly correlated with intensive margin employment growth both before and during the recent global financial crisis. Interestingly, the best performing surviving firms are estimated to be most negatively affected by a poor business environment. Institutional barriers thus appear as an important factor hampering firm growth in Central and Eastern Europe. These findings hold for the group of high-growth surviving firms (gazelles) that disproportionately accounted for the creation of new jobs in these economies.
\end{abstract}

JEL classification: L16; L21; L25; L51; L53

Keywords: Firm growth; Institutional barriers; Central and Eastern Europe

\section{Introduction}

In Central and Eastern European (CEE) countries $^{1}$, the structural change in economic activities over the last two decades involved two different developments. First, after the break-up of the former communist bloc, economic activities were reorganized into market-based economic systems. Second, as in other middle income economies, economic activity shifted away from agriculture and manufacturing to services, where the average firm size was relatively small but the number of firms large (see, e.g., Pilat et al. 2006). These structural changes had an impact on how, where and what type of jobs were created in the region (see, e.g. Raiser and Gill 2012).

After the vast majority of CEE countries successfully reorganized their centrally planned economies, they experienced varying degrees of success in creating productive jobs. Different levels of market regulations and entry barriers were crucial determinants explaining the differences in the economic structures across CEE countries.

\section{Springer}

(C) 2014 et al; licensee Springer. This is an Open Access article distributed under the terms of the Creative Commons Attribution License (http://creativecommons.org/licenses/by/2.0), which permits unrestricted use, distribution, and reproduction in any medium, provided the original work is properly cited. 
In general, countries that most successfully liberalized their economies, maintained macroeconomic stability and improved the quality of their business environment and institutions were able to create the conditions for firms to flourish and to attract the largest amounts of foreign direct investment (FDI). This, in turn, contributed not only to the structural changes in these economies, but also to the job-creation process and increased the attractiveness for FDI investors (see, e.g., Bevan and Estrin 2004, Pournarakis and Varsakelis 2004, Fabry and Zeghni 2006, Harding and Javorcik 2011, Jimenez et al. 2011, Crespo Cuaresma et al. 2012 and Tintin 2013).

The aim of this study is to understand the process of job creation at the intensive margin (i.e., within existing firms) in CEE economies over the last decade using firmlevel data. In particular, we assess the role that differences in the institutional environment across countries and sectors play as determinants of job creation dynamics (in surviving firms) in the region. The importance of the institutional setting as a factor fostering firm growth has been often emphasized in the literature (see Henrekson and Johansson 2009 or Henrekson and Johansson 2011, for two recent assessments of the importance of institutions in the firm growth process). In particular, institutions have been identified as a major determinant of the growth of enterprises during the transition process of CEE countries (see Peng and Heath 1996). Moreover, poor legal institutional regulations, such as corruption and financial constraints, have been identified to affect small and medium sized enterprises most negatively (see Beck et al. 2005).

The literature dealing with firm growth determinants in CEE countries is relatively limited. While some studies analyze empirically the factors affecting firm growth in countries of the region (see for example Konings 1997, Bilsen and Konings 1998, Konings and Xavier 2002, Studena 2004 or Hake 2009), the linkage between perceived institutional barriers and existing firm employment growth in CEE countries at the firm level has not been explicitly dealt with hitherto in the literature. Furthermore, our contribution uses for the first time data for CEE firms which cover the recent financial crisis. Since the economic downturn induced by the financial crisis may have triggered yet another structural change in the region, a clear understanding of the key industry and firm-specific determinants of job creation within existing firms before and after the crisis is important for both policy makers and entrepreneurs.

Our empirical analysis combines information from the Amadeus database (provided by Bureau van Dijk, which contains comparable and comprehensive balance sheet and profit and loss account data for the eleven countries under study for a time period spanning from 2002 to 2009) with data from the World Bank's Business Environment and Enterprise Performance Survey (BEEPS), which collects information on the business environment in which the firms operate. In the CEE region, these surveys have been conducted in the years 2002, 2005, 2007 and 2009, allowing the analysis of intensive margin dynamics of job creation at the firm level in the boom years prior to the global financial crisis as well as during the "bust" period.

Our results indicate that more productive existing firms tend to be less affected by economic downturns and that intensive margin employment growth at the firm level is correlated with the perceived quality of the business climate by CEE enterprises. For the post-crisis period, our estimates show that the overall level of institutional barriers have had a significant negative effect on employment growth in high-growth surviving 
firms, which are precisely those that disproportionately account for the creation of new jobs in CEE economies.

The paper is organized as follows. Section 2 presents stylized facts on job creation in CEE economies. Section 3 offers an econometric analysis of intensive margin job creation patterns at the firm level with the aim of isolating the effects of the institutional setting on firm growth within existing firms. We additionally apply quantile regressions to analyze how the effect of institutional barriers on employment growth depends on the relative performance of firms. Section 4 investigates the role played by industry and firm-specific characteristics on the likelihood of belonging to the group of high-growth surviving firms. Such an analysis allows us to understand the nature of the factors promoting job creation in CEE countries and informs policymakers about the potential effects of changes in the regulatory framework on intensive margin job creation. Section 5 concludes and offers policy conclusions based on our empirical results.

\section{Job creation at the firm level and business environment perceptions in CEE economies: the stylized facts}

In order to analyze the characteristics of intensive margin job creation in the region, we use the Amadeus database to construct a variable measuring yearly employment growth for all available firms from CEE economies and spanning the years 2002 to 2009. This leads to a dataset of 2,590,137 firm-year observations for the eleven economies consid$\operatorname{ered}^{2}$. The main advantage of this data source is that it captures not only medium and large firms, but also some very small firms. The minimum number of employees of the recorded firms is one worker. The data at hand, therefore, allow to accurately address the question whether small or large surviving firms are more important net job creators.

The database, however, also has at least three notable drawbacks. First, Amadeus reports poor information on market entry and exit. Consequently, our analysis of job creation is limited to the impact of certain firm and industry characteristics for surviving firms and, thus, we focus on intensive margin job creation. Second, the quality of the Amadeus data substantially varies across countries. The main reason for this is that Bureau van Dijk, the commercial supplier of Amadeus, puts together firm-level data that are provided by national data collectors, which in turn often concentrate on different types of information. For example, for firms located in Croatia, Estonia and Lithuania only limited financial data are provided which do not contain any information on value added or costs of employees ${ }^{3}$. Finally, as highlighted by Klapper et al. (2002) some of the information reported in the Amadeus database might simply be carried over from one year to another, leading to the impression that certain variables remained constant over time when in reality the companies just did not update the corresponding information. In such cases, a zero growth rate of employment would not reflect the real changes in employment but rather would be induced by data collection issues. In our empirical analysis, we try to limit this issue by excluding all observations where at least two of three important balance sheet items including employment, revenues and total assets amount exactly to the same value over two consecutive years. We exclude all observations with simultaneous zero growth rates for employment and revenues, employment and total assets or revenues and total assets.

Figure 1 shows the ratio of total employment in 2008 to employment in 2002 derived from the Amadeus data, as well as the same ratio for the years 2009 and $2002^{4}$. On 


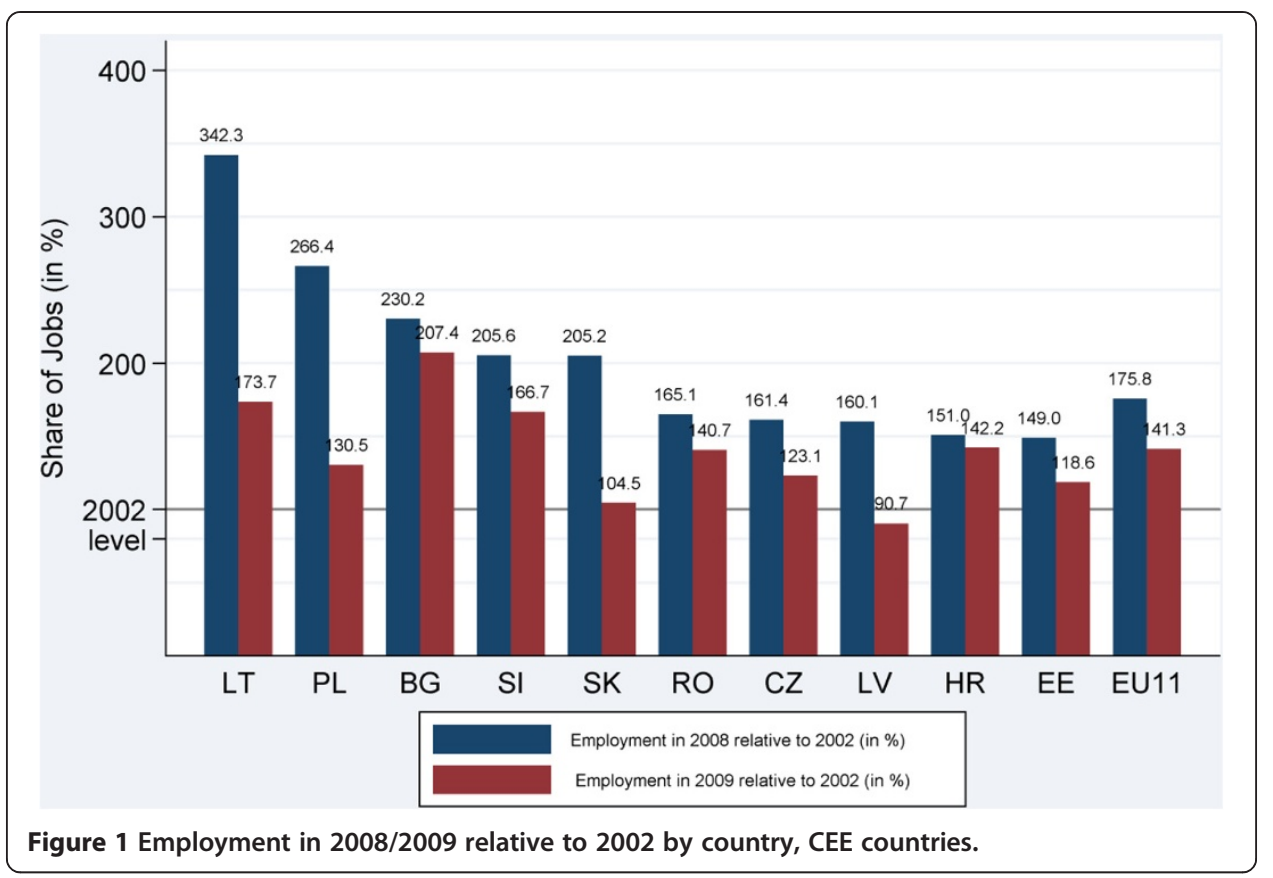

average among the surveyed firms, the number of employees in firms that were already active in 2002 increased by approximately 76 percent. Many jobs created in CEE economies during the period 2002-2008 were actually lost during the 2008 global financial crisis. In the six first years of the period considered the minimum increase in the number of workers amounted to approximately 50 percent across all countries. At the intensive margin, Lithuania, Poland, Bulgaria, Slovenia and Slovakia were able to more than double the number of employed workers. However, the global financial crisis induced a substantial overall job loss in 2009, nearly halving the cumulative gains of the previous period from 2002 to 2008. Interestingly, in Poland the sharp reduction of employment in active firms has been associated with a decrease in real GDP. In contrast to all other CEE countries which experienced (substantial) negative real GDP growth rates, Poland's GDP grew at a rate of 1.6\% (see Eurostat 2013). However, Poland's unemployment rate also increased after 2008, which is consistent with the firm level data from the Amadeus database.

The average job creation rates among surviving firms also differed substantially across industries, as can be seen in Figure 2, which depicts average employment growth by sector and year. Prior to the financial crisis, the average intensive margin employment growth among the surveyed firms was smallest in agricultural and fishing and largest in construction and in the transport, storage and communications industries. This is in line with more aggregated data showing that different types of service industries also gain importance in the CEE economies. Interestingly, in 2009 only two sectors registered positive intensive margin employment growth rates - agriculture and fishing and the other services industries. The average intensive margin job destruction rate in 2009 amounted to 4.4 percent in the construction industry alone. While existing firms in the manufacturing sector experienced decent job creation rates from 2002 to 2008, they were most severely affected by the 2008 global financial crisis, with an average intensive margin job destruction rate of around 6 percent in 2009. 


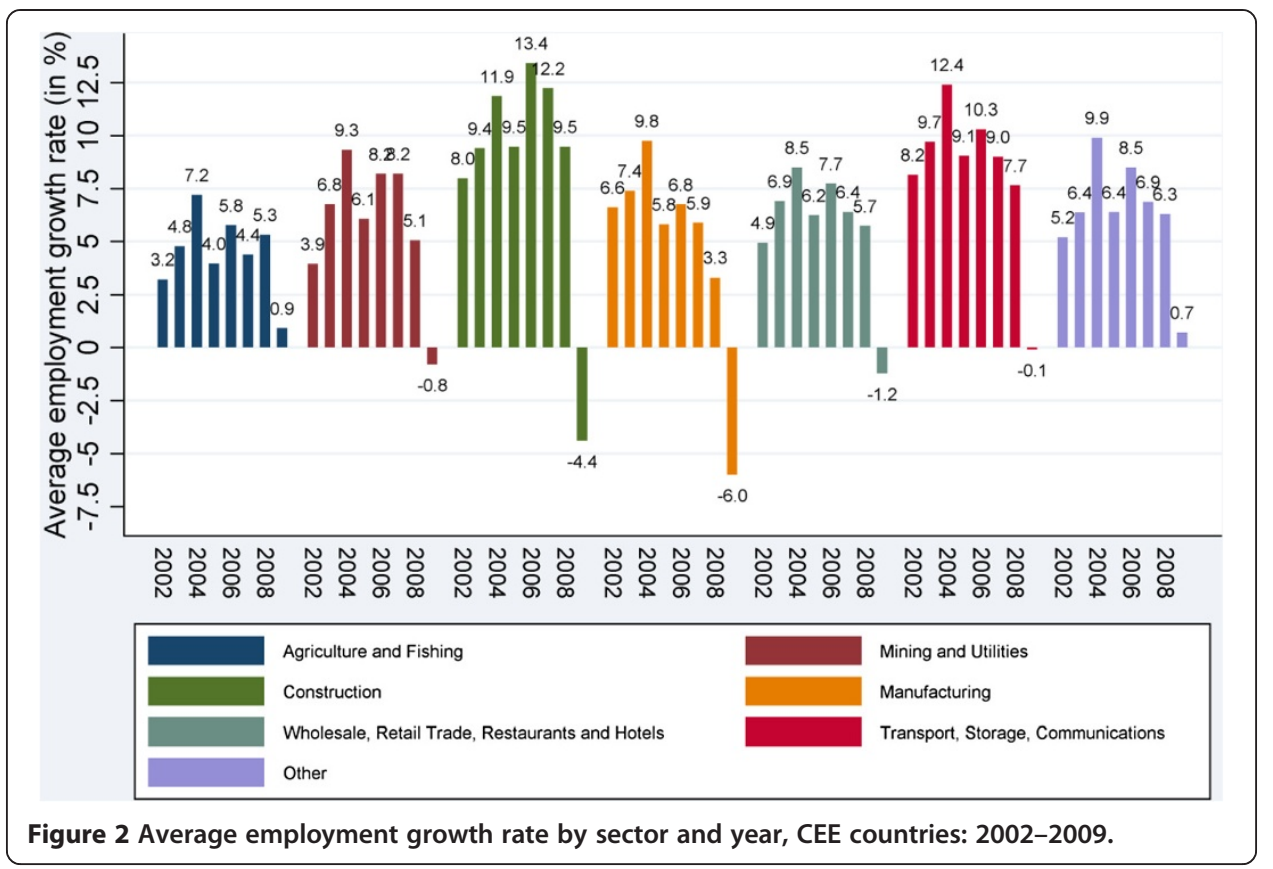

The BEEPS dataset allows us to link such developments in employment with information about the business environment perceptions that are available at a 2-digit industry level of aggregation. The BEEPS database is collected by the World Bank and reports detailed survey information on firms located all over the world. The average business barriers index is based on questions regarding perceived barriers for doing business in the categories institutional regulations, access to finance, crime, corruption, taxation, labor regulations, infrastructure and law. The specific questions used for the construction are reported in the Additional file 1 and the answers to each question range from 0 (no obstacle) to 4 (very severe obstacle). For the construction of the overall business barriers index we first average the replies to all questions for each firm and, subsequently, construct the industry index by averaging all averages within each 2-digit industries. This approach is necessary because the firms surveyed in the BEEPS dataset cannot be directly linked with the firms collected in the Amadeus database. In contrast to other data sources, such as the World Economic Outlook (WEO) data provided by the IMF, the World Bank's Doing Business indicators and OECD's product market competition indicators, the BEEPS data have some advantages for the aim of this paper. First, the Doing Business indicators and the WEO data are only available at the country level and do not allow to link within-country variation in intensive margin employment growth to differences in institutional barriers for doing business. The OECD's product market competition indicators are collected at the sectorial level but are only available for very few industries such as professional services, retail trade and energy, transport and communications. A drawback of the product market competition indicators as well as the BEEPS data is that the surveys are not conducted every year. In our case, the BEEPS data are only available for the years 2002, 2005, 2007 and 2009 and not all included firms are surveyed in all four waves of the questionnaire. In our econometric approach, discussed in Sections 3 and 4, we take this data limitation into account. 


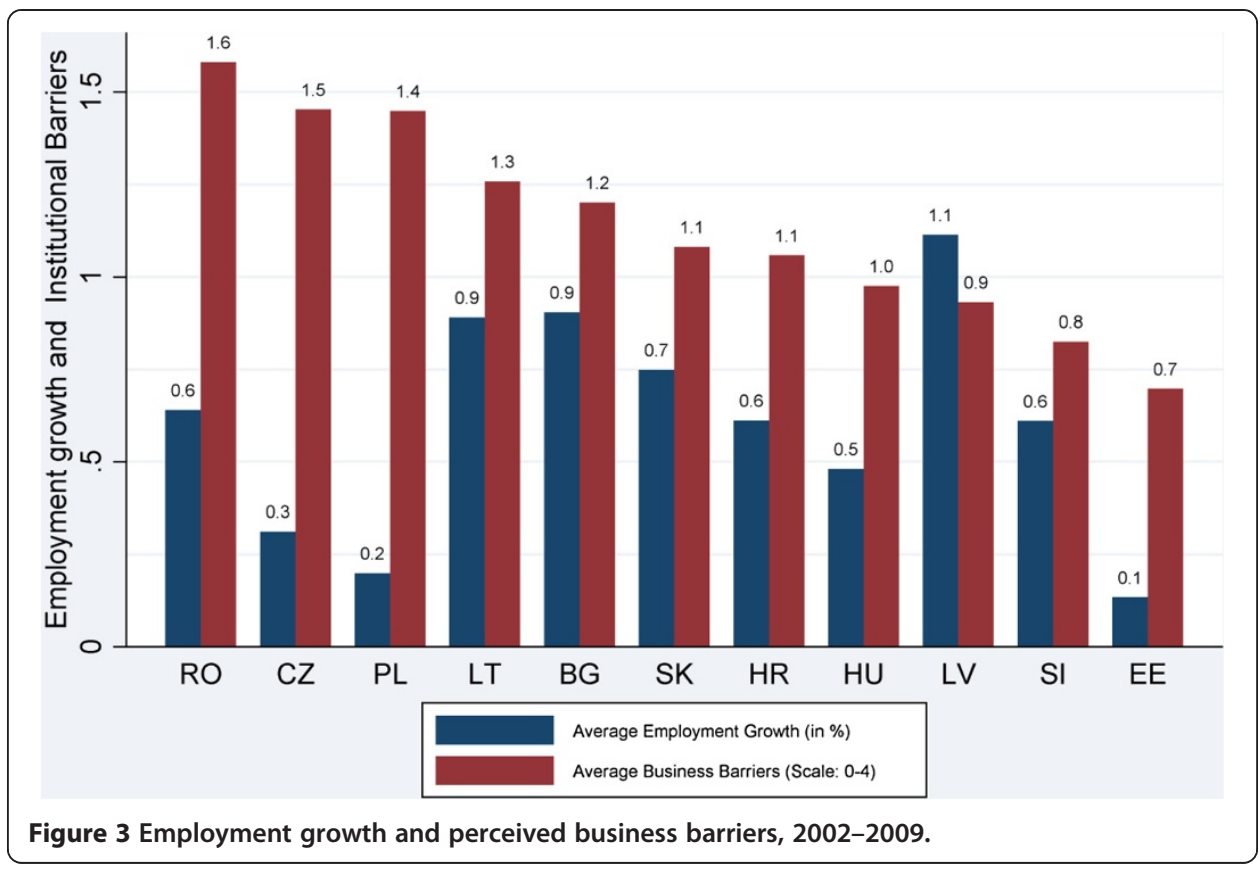

Figure 3 presents the average business barriers index from the BEEPS dataset together with average intensive margin employment growth for the countries in our sample. At the country level, Romania was perceived to be the most business unfriendly country ${ }^{5}$. Romania, the Czech Republic, and Poland were all perceived to have had institutional obstacles to doing business and experienced below average intensive margin employment growth rates in the observed period.

Latvia, on the other hand, was perceived as a relatively business friendly economy and showed the highest average employment growth rates in existing firms in our group of CEE economies. Interestingly, however, jobs in Latvia were strongly affected by the financial crisis, while employment in Romania remained relatively stable. Estonia the most business amicable country between 2002 and 2009 according to this index however saw its intensive margin employment growth lag behind the other economies in the region. Some countries such as Bulgaria were perceived to have relatively unfriendly business environments, but the average job creation rates of existing firms located in these economies were above the average of the CEE region.

Given such ambiguous empirical stylized facts, the question of whether firm-level employment performance in existing firms differs across CEE countries with different quality of business institutions appears warranted. With this hypothesis at hand, the rest of the paper investigates econometrically the industry and firm-specific determinants of the intensive margin job creation process in the CEE region and specifically analyzes the role of institutional barriers to growth.

\section{The empirical determinants of firm growth in CEE countries: how much do institutional barriers matter?}

In order to assess econometrically the effects of the business climate and other covariates on the growth performance of surviving enterprises in CEE countries, we apply firm growth equations in the spirit of Gibrat's law (see, e.g., Hart 2000, Coad 2009 and 
Coad and Hölzl 2012, for surveys). For this purpose, we construct a cross-section of firm and business barriers data and analyze an existing firm's average annual employment growth rate over the time period 2002 and 2008. A separate regression analysis solely focuses on the post-crisis year 2009. Certain characteristics of the data at hand justify the use of this approach. First, the time dimension of the Amadeus database is relatively poor, leading to a large number of missing observations within each year. This implies that the number of available years differ across firms. In our regression analysis we follow Oberhofer (2013) and account for this problem by including an additional covariate that measures the number of observed years for the calculation of the average annual employment growth rate $^{6}$. Firm-specific data are relatively persistent over time, inducing very low within-firm variation. Moreover, the BEEPS data are only collected in some of the observed years, thus not allowing us to perform an analysis of the impact of the perceived business barriers for intensive margin employment growth at the annual frequency. Finally, in the literature on Gibrat's law, the cross-sectional approach is not unusual, since through the calculation of annual average employment growth rates it allows to investigate medium to long-run relationships between covariates of interest and the growth performance of existing firms.

A cross-sectional Gibrat-law type of regression can be written as (see, e.g., Geroski 2005 and Oberhofer and Pfaffermayr 2013):

$$
\begin{aligned}
& g_{i j}=\alpha+\pi_{i j} S_{0 i j}+\boldsymbol{x}_{i j} \boldsymbol{\gamma}+\boldsymbol{z}_{j} \boldsymbol{\delta}+\varepsilon_{i}, \\
& \pi_{i j}=\beta_{0}+\beta_{1} A_{i j} .
\end{aligned}
$$

Equations (1) and (2) state that the intensive margin average employment growth rate $g_{i j}$ of firm $i$ in industry $j$ is a function of $(\log )$ initial firm size $S_{0 i}{ }^{7}$ (i.e., the number of employees in the first observed period) and other firm and industry-specific control variables collected in $\boldsymbol{x}_{i j}$ and $\boldsymbol{z}_{j}$, respectively. $\boldsymbol{y}$ and $\boldsymbol{\delta}$ are column vectors of parameters to be estimated. $\pi_{i j}$ captures the (conditional) speed of convergence/divergence, which is assumed to be firm-specific and is modeled to depend on firm age $A_{i j}$.

One standard result in the empirical firm growth literature states that the observed speed of convergence declines with age. This finding would be confirmed in this application if the estimated parameters fulfill that $\beta_{0}<0$ and $\beta_{1}>0$. Economically, such a result would suggest that younger and smaller firms grow faster, while old small firms would not exhibit increased employment growth dynamics ${ }^{8}$.

In order to address the potential structural breaks in the relationships given by equations (1) and (2) which are caused by the global financial crisis, we estimate the model for two periods, the first one spanning the years 2002 to 2008 and the second one for 2008-2009. In each case the specification is estimated using a cross section of firms where the dependent variable is the intensive margin growth rate of employment (average over 2002-2008 in the first case and for the year 2009 in the second case). The sample captures only surviving firms, making it therefore impossible to examine exit dynamics.

The vector $z_{j}$ contains industry dummy variables and business environment indicators. Using the BEEPS dataset, we construct an indicator that measures the average institutional barriers within 2-digit industries and countries. The overall industry-country specific measure for institutional barriers is based on different questions concerning 
perceived obstacles for conducting business that are included in the BEEPS data. In particular, this general indicator comprises information on the degree of institutional regulations, access to finance, crime, corruption, taxation and labor regulations. Moreover, the overall business barriers indicator also contains questions on infrastructure and law related business restrictions. In alternative specifications, the effects of these specific business barriers on job creation are investigated separately while we control for all other business barriers. Accordingly, the overall institutional barriers index is always calculated without including the specific barrier considered in the specifications where it is included. With regard to additional firm-specific controls collected in $\boldsymbol{x}_{i j}$, (log) firm age, (log) firm's total factor productivity (TFP) and an indicator variable for foreign ownership are included. TFP is estimated via the approach suggested by Levinsohn and Petrin (2003), which uses a firm's demand for intermediate inputs (such as materials) in order to overcome the problem of simultaneity when estimating firm level production functions ${ }^{9}$. The dummy variable for foreign ownership aims at picking up structural differences in the intensive margin growth performance between domestically controlled firms and subsidiaries of multinational corporate groups.

Tables 1 and 2 report the corresponding estimation results for the pre-crisis period and the year 2009, respectively. Starting with the period 2002-2008, at the firm level and the intensive margin traditional industries were the key creators of new jobs to the crisis. Employment growth was fastest in the construction and manufacturing industries and slowest in the service industries. When controlling for differences in firmcharacteristics (especially for firm size differentials), employment growth within existing firms was slowest in the group of other industries, which mainly consisted of services firms ${ }^{10}$. Across different specifications of the firm growth model, an average surviving construction firm was estimated to grow by 3.8 (see column 1 of Table 1) to 6.1 (see e.g., column 6) percentage points more annually in comparison to a firm of the same size, age, and productivity in the "other services" sector. The intensive margin figure for manufacturing firms varied between 3.2 and 4.1 percentage points. With the exception of the first specification continuing agricultural and fishing firms are also estimated to growth faster than other service firms. This quantitative effect ranges from 1.2 to 3.3 percentage points. In a similar vein, we also estimate positive intensive margin job creation effects for firms operating in the wholesale, retail trade, hotel and restaurants as well as the transport, storage and communications industries in the majority of our alternative specifications. However, the quantitative effect seems to be larger in more traditional sectors.

At a first glance, this last result seems to be partially in contrast with macro-level evidence which indicates that service firms are responsible for two-thirds of gross value added in the CEE economies. Firms operating in the service sector were indeed important in terms of overall value added but, based on our estimates, they did not contribute overwhelmingly to intensive margin job creation ${ }^{11}$. The number of firms that operate in the services sector in the region was very large (around 72 percent of all sampled firms were service providers), but these firms were relatively small. In more traditional sectors, the average firm size was much larger and, therefore, they strongly contributed to overall intensive margin job creation in 2002-2008. Controlling for differences in firm-specific total factor productivity and with the exception of the construction industries, service industries were estimated to create jobs at a slower pace than firms in the rest of the economy. 
Table 1 Estimation results for annual average firm growth, 2002-2008

\begin{tabular}{|c|c|c|c|c|c|c|c|c|}
\hline Variables & $\begin{array}{l}\text { No regulations } \\
\text { (1) }\end{array}$ & $\begin{array}{l}\text { Overall inst. } \\
\text { (2) }\end{array}$ & $\begin{array}{l}\text { Inst. regulation } \\
\text { (3) }\end{array}$ & $\begin{array}{l}\text { Access to finance } \\
\text { (4) }\end{array}$ & $\begin{array}{l}\text { Crime } \\
(5)\end{array}$ & $\begin{array}{l}\text { Corruption } \\
\text { (6) }\end{array}$ & $\begin{array}{l}\text { Tax } \\
\text { (7) }\end{array}$ & $\begin{array}{l}\text { Labor regulation } \\
\text { (8) }\end{array}$ \\
\hline \multicolumn{9}{|c|}{ Firm characteristics } \\
\hline \multirow[t]{2}{*}{ Initial size } & $-0.053^{* * *}$ & $-0.078^{* * *}$ & $-0.079^{* * *}$ & $-0.078^{* * *}$ & $-0.078^{* * *}$ & $-0.078^{* * *}$ & $-0.079^{* * *}$ & $-0.078^{* * *}$ \\
\hline & $(0.003)$ & $(0.005)$ & $(0.005)$ & $(0.005)$ & $(0.005)$ & $(0.005)$ & $(0.005)$ & $(0.005)$ \\
\hline \multirow[t]{2}{*}{ Age } & $-0.046^{* * *}$ & $-0.076^{* * *}$ & $-0.077^{* * *}$ & $-0.076^{* * *}$ & $-0.076^{* * *}$ & $-0.076^{* * *}$ & $-0.077^{* * *}$ & $-0.076^{* * *}$ \\
\hline & $(0.002)$ & $(0.006)$ & $(0.005)$ & $(0.006)$ & $(0.006)$ & $(0.006)$ & $(0.006)$ & $(0.006)$ \\
\hline \multirow[t]{2}{*}{ Initial size $\times$ age } & $0.005^{* * *}$ & $0.013^{* * *}$ & $0.013^{* * *}$ & $0.013^{* * *}$ & $0.013^{* * *}$ & $0.013^{* * *}$ & $0.013^{* * *}$ & $0.013^{* * *}$ \\
\hline & $(0.001)$ & $(0.002)$ & $(0.002)$ & $(0.002)$ & $(0.002)$ & $(0.002)$ & $(0.002)$ & $(0.002)$ \\
\hline \multirow[t]{2}{*}{ TFP } & - & $0.015^{* * *}$ & $0.015^{* * *}$ & $0.015^{* * *}$ & $0.015^{* * *}$ & $0.015^{* * *}$ & $0.015^{* * *}$ & $0.015^{* * *}$ \\
\hline & - & $(0.002)$ & $(0.002)$ & $(0.002)$ & $(0.002)$ & $(0.002)$ & $(0.002)$ & $(0.002)$ \\
\hline \multirow[t]{2}{*}{ Foreign owner } & - & $0.035^{* * *}$ & $0.035^{* * *}$ & $0.034^{* * *}$ & $0.035^{* * *}$ & $0.035^{* * *}$ & $0.036^{* * *}$ & $0.035^{* * *}$ \\
\hline & - & $(0.008)$ & $(0.008)$ & $(0.008)$ & $(0.008)$ & $(0.008)$ & $(0.008)$ & $(0.008)$ \\
\hline \multicolumn{9}{|c|}{ Industry characteristics } \\
\hline \multirow[t]{2}{*}{ Agriculture } & 0.004 & $0.032^{* * *}$ & $0.012^{*}$ & $0.013^{*}$ & $0.033^{* * *}$ & $0.032^{* * *}$ & $0.026^{* * *}$ & $0.033^{* * *}$ \\
\hline & $(0.003)$ & $(0.004)$ & $(0.006)$ & $(0.007)$ & $(0.003)$ & $(0.003)$ & $(0.004)$ & $(0.003)$ \\
\hline \multirow[t]{2}{*}{ Mining } & $0.043^{* * *}$ & - & - & - & - & - & - & - \\
\hline & $(0.009)$ & - & - & - & - & - & - & - \\
\hline \multirow[t]{2}{*}{ Construction } & $0.038^{* * *}$ & $0.061^{* * *}$ & $0.043^{* * *}$ & $0.049^{* * *}$ & $0.061^{* * *}$ & $0.061^{* * *}$ & $0.054^{* * *}$ & $0.061^{* * *}$ \\
\hline & $(0.006)$ & $(0.009)$ & $(0.010)$ & $(0.009)$ & $(0.009)$ & $(0.009)$ & $(0.010)$ & $(0.009)$ \\
\hline \multirow[t]{2}{*}{ Manufacturing } & $0.032^{* * *}$ & $0.041^{* * *}$ & $0.022^{* * *}$ & $0.033^{* * *}$ & $0.042^{* * *}$ & $0.040^{* * *}$ & $0.032^{* * *}$ & $0.041^{* * *}$ \\
\hline & $(0.006)$ & $(0.006)$ & $(0.007)$ & $(0.006)$ & $(0.006)$ & $(0.008)$ & $(0.006)$ & $(0.006)$ \\
\hline \multirow[t]{2}{*}{ Wholesale } & 0.006 & $0.015^{* * *}$ & 0.000 & 0.005 & $0.015^{* * *}$ & $0.014^{* * *}$ & 0.005 & $0.016^{* * *}$ \\
\hline & $(0.005)$ & $(0.002)$ & $(0.004)$ & $(0.004)$ & $(0.002)$ & $(0.002)$ & $(0.004)$ & $(0.002)$ \\
\hline
\end{tabular}


Table 1 Estimation results for annual average firm growth, 2002-2008 (Continued)

\begin{tabular}{|c|c|c|c|c|c|c|c|c|}
\hline \multirow[t]{2}{*}{ Transport } & $0.017^{* *}$ & $0.019^{* *}$ & 0.004 & $0.014^{* *}$ & $0.020^{* *}$ & $0.018^{* *}$ & $0.015^{* * *}$ & $0.020^{* *}$ \\
\hline & $(0.007)$ & $(0.008)$ & $(0.005)$ & $(0.005)$ & $(0.008)$ & $(0.009)$ & $(0.005)$ & $(0.009)$ \\
\hline \multirow[t]{2}{*}{ Overall inst. ${ }^{a)}$} & - & -0.009 & $-0.031^{* *}$ & 0.016 & -0.013 & 0.004 & 0.005 & -0.015 \\
\hline & - & $(0.010)$ & $(0.011)$ & $(0.010)$ & $(0.015)$ & $(0.015)$ & $(0.010)$ & $(0.013)$ \\
\hline \multirow[t]{2}{*}{ Inst. regulation } & - & - & $0.025^{* * *}$ & - & - & - & - & - \\
\hline & - & - & $(0.008)$ & - & - & - & - & - \\
\hline \multirow[t]{2}{*}{ Access to finance } & - & - & - & $-0.027^{* * *}$ & - & - & - & - \\
\hline & - & - & - & $(0.010)$ & - & - & - & - \\
\hline \multirow[t]{2}{*}{ Crime } & - & - & - & - & 0.004 & - & - & - \\
\hline & - & - & - & - & $(0.009)$ & - & - & - \\
\hline \multirow[t]{2}{*}{ Corruption } & - & - & - & - & - & -0.005 & - & - \\
\hline & - & - & - & - & - & $(0.010)$ & - & - \\
\hline \multirow[t]{2}{*}{ Taxation } & - & - & - & - & - & - & $-0.020^{* * *}$ & - \\
\hline & - & - & - & - & - & - & $(0.007)$ & \\
\hline \multirow[t]{2}{*}{ Labor regulation } & - & - & - & - & - & - & - & 0.007 \\
\hline & - & - & - & - & - & - & - & $(0.008)$ \\
\hline \multicolumn{9}{|l|}{ Fixed effects } \\
\hline \multirow[t]{2}{*}{ Country } & $198.83^{* * *}$ & $135.73^{* * *}$ & $122.51^{* * *}$ & $124.18^{* * *}$ & $86.91^{* * *}$ & $165.00^{* * *}$ & $139.77^{* * *}$ & $145.88^{* * *}$ \\
\hline & $R^{2}$ & 0.097 & 0.139 & 0.141 & 0.140 & 0.139 & 0.139 & 0.140 \\
\hline Observations & 180,932 & 34,086 & 34,086 & 34,086 & 34,086 & 34,086 & 34,086 & 34,086 \\
\hline
\end{tabular}

Notes: The dependent variable is the average annual employment growth rate for the period 2002-2008. Constant not reported. Clustered standard errors (at the 2-digit industry level) in parenthesis. **** and *** denote significance at 10 percent, 5 percent and 1 percent levels, respectively. ${ }^{a)}$ In columns (3)-(8) the overall institutional barriers are calculated without including the questions on the respective specific institutional barrier investigated. The coefficient for the number of observed years is not reported. 
Table 2 Estimation results for annual average firm growth in 2009

\begin{tabular}{|c|c|c|c|c|c|c|c|c|}
\hline Variables & $\begin{array}{l}\text { No regulations } \\
\text { (1) }\end{array}$ & $\begin{array}{l}\text { Overall inst. } \\
\text { (2) }\end{array}$ & $\begin{array}{l}\text { Inst. regulation } \\
\text { (3) }\end{array}$ & $\begin{array}{l}\text { Access to finance } \\
\text { (4) }\end{array}$ & $\begin{array}{l}\text { Crime } \\
(5)\end{array}$ & $\begin{array}{l}\text { Corruption } \\
\text { (6) }\end{array}$ & $\begin{array}{l}\text { Tax } \\
\text { (7) }\end{array}$ & $\begin{array}{l}\text { Labor regulation } \\
\text { (8) }\end{array}$ \\
\hline \multicolumn{9}{|c|}{ Firm characteristics } \\
\hline \multirow[t]{2}{*}{ Initial size } & $-0.073^{* * *}$ & $-0.075^{* * *}$ & $-0.075^{* * *}$ & $-0.075^{* * *}$ & $-0.075^{* * *}$ & $-0.075^{* * *}$ & $-0.075^{* * *}$ & $-0.075^{* * *}$ \\
\hline & $(0.005)$ & $(0.006)$ & $(0.006)$ & $(0.006)$ & $(0.006)$ & $(0.006)$ & $(0.006)$ & $(0.006)$ \\
\hline \multirow[t]{2}{*}{ Age } & $-0.038^{* * *}$ & $-0.054^{* * *}$ & $-0.054^{* * *}$ & $-0.054^{* * *}$ & $-0.054^{* * *}$ & $-0.054^{* * *}$ & $-0.054^{* * *}$ & $-0.055^{* * *}$ \\
\hline & $(0.003)$ & $(0.006)$ & $(0.006)$ & $(0.006)$ & $(0.006)$ & $(0.006)$ & $(0.005)$ & $(0.006)$ \\
\hline \multirow[t]{2}{*}{ Initial size $\times$ age } & $0.016^{* * *}$ & $0.016^{* * *}$ & $0.016^{* * *}$ & $0.016^{* * *}$ & $0.016^{* * *}$ & $0.016^{* * *}$ & $0.016^{* * *}$ & $0.016^{* * *}$ \\
\hline & $(0.001)$ & $(0.002)$ & $(0.002)$ & $(0.002)$ & $(0.002)$ & $(0.002)$ & $(0.002)$ & $(0.002)$ \\
\hline \multirow[t]{2}{*}{ TFP } & & $0.039^{* * *}$ & $0.039^{* * *}$ & $0.039^{* * *}$ & $0.039^{* * *}$ & $0.039^{* * *}$ & $0.039^{* * *}$ & $0.039^{* * *}$ \\
\hline & & $(0.002)$ & $(0.002)$ & $(0.002)$ & $(0.002)$ & $(0.002)$ & $(0.002)$ & $(0.002)$ \\
\hline \multirow[t]{2}{*}{ Foreign owner } & - & $0.039^{* * *}$ & $0.039^{* * *}$ & $0.039^{* * *}$ & $0.040^{* * *}$ & $0.040^{* * *}$ & $0.039^{* * *}$ & $0.040^{* * *}$ \\
\hline & - & $(0.011)$ & $(0.011)$ & $(0.011)$ & $(0.011)$ & $(0.011)$ & $(0.011)$ & $(0.011)$ \\
\hline \multicolumn{9}{|c|}{ Industry characteristics } \\
\hline \multirow[t]{2}{*}{ Agriculture } & $0.026^{* *}$ & $-0.065^{* * *}$ & $-0.055^{* * *}$ & $-0.058^{* * *}$ & $-0.062^{* * *}$ & $-0.048^{* * *}$ & $-0.059^{* * *}$ & $-0.053^{* * *}$ \\
\hline & $(0.012)$ & $(0.008)$ & $(0.006)$ & $(0.009)$ & $(0.007)$ & $(0.011)$ & $(0.014)$ & (0.009) \\
\hline \multirow[t]{2}{*}{ Mining } & $0.032^{* * *}$ & - & - & - & - & - & - & - \\
\hline & $(0.013)$ & - & - & - & - & - & - & - \\
\hline \multirow[t]{2}{*}{ Construction } & $-0.035^{* * *}$ & $-0.050^{* * *}$ & $-0.040^{* *}$ & $-0.044^{* *}$ & $-0.049^{* * *}$ & $-0.031^{*}$ & $-0.047^{* *}$ & $-0.035^{* *}$ \\
\hline & $(0.010)$ & $(0.016)$ & $(0.015)$ & (0.018) & $(0.016)$ & $(0.016)$ & $(0.017)$ & $(0.014)$ \\
\hline \multirow[t]{2}{*}{ Manufacturing } & -0.018 & $-0.074^{* * *}$ & $-0.066^{* * *}$ & $-0.070^{* * *}$ & $-0.071^{* * *}$ & $-0.070^{* * *}$ & $-0.070^{* * *}$ & $-0.065^{* * *}$ \\
\hline & $(0.013)$ & $(0.018)$ & $(0.020)$ & $(0.018)$ & $(0.026)$ & $(0.021)$ & $(0.017)$ & $(0.021)$ \\
\hline \multirow[t]{2}{*}{ Wholesale } & -0.004 & $-0.017^{* *}$ & -0.006 & -0.012 & $-0.016^{* * *}$ & -0.007 & -0.013 & $-0.010^{*}$ \\
\hline & $(0.006)$ & $(0.007)$ & $(0.005)$ & $(0.008)$ & $(0.006)$ & $(0.005)$ & $(0.010)$ & $(0.006)$ \\
\hline
\end{tabular}


Table 2 Estimation results for annual average firm growth in 2009 (Continued)

\begin{tabular}{|c|c|c|c|c|c|c|c|c|}
\hline \multirow[t]{2}{*}{ Transport } & -0.002 & $-0.042^{* * *}$ & $-0.034^{* * *}$ & $-0.038^{* * *}$ & $-0.042^{* * *}$ & $-0.037^{* * *}$ & $-0.042^{* * *}$ & $-0.041^{* * *}$ \\
\hline & $(0.009)$ & $(0.008)$ & $(0.006)$ & $(0.008)$ & $(0.007)$ & $(0.005)$ & $(0.009)$ & $(0.007)$ \\
\hline \multirow[t]{2}{*}{ Overall inst.a) } & - & -0.011 & -0.005 & -0.004 & -0.014 & -0.008 & -0.012 & -0.004 \\
\hline & - & $(0.015)$ & $(0.011)$ & $(0.016)$ & $(0.026)$ & (0.009) & $(0.013)$ & $(0.011)$ \\
\hline \multirow[t]{2}{*}{ Inst. regulation } & - & - & -0.016 & - & - & - & - & - \\
\hline & - & - & $(0.012)$ & - & - & - & - & - \\
\hline \multirow[t]{2}{*}{ Access to finance } & - & - & - & -0.011 & - & - & - & - \\
\hline & - & - & - & $(0.008)$ & - & - & - & - \\
\hline \multirow[t]{2}{*}{ Crime } & - & - & - & - & 0.005 & - & - & - \\
\hline & - & - & - & - & $(0.020)$ & - & - & - \\
\hline \multirow[t]{2}{*}{ Corruption } & - & - & - & - & - & -0.027 & - & - \\
\hline & - & - & - & - & - & $(0.020)$ & - & - \\
\hline \multirow[t]{2}{*}{ Taxation } & - & - & - & - & - & - & -0.010 & - \\
\hline & - & - & - & - & - & - & $(0.012)$ & \\
\hline \multirow[t]{2}{*}{ Labor regulations } & - & - & - & - & - & - & - & -0.026 \\
\hline & - & - & - & - & - & - & - & $(0.017)$ \\
\hline \multicolumn{9}{|l|}{ Fixed effects } \\
\hline Country & $69.04^{* * *}$ & $67.76^{* * *}$ & $68.37^{* * *}$ & $67.64^{* * *}$ & $52.62^{* * *}$ & $82.22^{* * *}$ & $69.19^{* * *}$ & $98.15^{* * *}$ \\
\hline$R^{2}$ & 0.040 & 0.050 & 0.050 & 0.050 & 0.050 & 0.050 & 0.050 & 0.050 \\
\hline Observations & 299,695 & 71,157 & 71,201 & 71,162 & 71,157 & 71,157 & 71,157 & 71,157 \\
\hline
\end{tabular}

Notes: The dependent variable is the yearly employment growth rate for the period 2008-2009. Constant not reported. Clustered standard errors (at the 2-digit industry level) in parenthesis. * ** and *** denote

significance at 10 percent, 5 percent and 1 percent levels, respectively. ${ }^{a)}$ In columns (3)-(8) the overall institutional barriers are calculated without including the questions on the respective specific institutional

barrier investigated. 
In line with typical estimation results from empirical firm growth equations á la Gibrat's law (see, e.g., Coad 2009 and Oberhofer 2012), the average intensive margin employment growth rate was largest in the initially smallest firms. The empirical results show that a one percent increase in the initial firm size (i.e., the firm size at the first observed year) decreases the average annual job creation rate by 5.3 to 7.9 percentage points. Hence, small surviving firms in CEE economies prior to the crisis tended to rapidly adjust their size to favorable market conditions.

At the same time, start-ups and (very) young surviving firms grew at the fastest pace. This finding holds true for both initially small and large firms. However, it is important to note that our data do not allow for ascertaining whether the prevailing characteristic of fast-growing firms is age or size. Recent findings in the literature with more adequate data for the USA (e.g., Haltiwanger et al. 2013) conclude that it is age rather than firm size that matters, so that the job creation in surviving start-ups and young firms outperformed the intensive margin employment growth rates of older firms ${ }^{12}$.

The employment growth performance of small old surviving firms was substantially worse. The positive parameter estimates for the interaction effect of firm size and firm age indicates that the speed of adjustment was slower for surviving firms with relatively small size and relatively old age. While small firms contribute to job creation when they are young, in later periods their number of employees tends to stabilize.

Productive firms contributed positively to intensive margin job creation. In quantitative terms, a one percent increase in firm-specific total factor productivity (TFP) increases average employment growth in existing firms by approximately 1.5 percentage points. This finding is robust across all different specifications, and driven by differences in the initial level of productivity ${ }^{13}$. If more productive firms compete more successfully than less productive firms on the domestic and the world markets, this enables them to expand their level of production. This expansion may have also increased the firms' labor demand and, therefore, accelerated intensive margin job creation rates. Prior to the crisis, thus, labor resources appear to have efficiently reached firms with growing productivity. The positive effect of productivity on employment growth also indicates that efficient firms within industries were able to grow more rapidly than the rest. Moreover, the quantitative dimension of the effect points to the usefulness of creating an economic environment that stimulates productivity growth. An existing firm that, for example, successfully increased its level of TFP by 10 percentage points (through e.g., innovation, learning-by-doing or technology adoption) expanded its employment on average by 15 percentage points more between 2002 and 2008.

In a similar vein, we are also able to estimate a significant and positive intensive margin job creation effect for subsidiaries of multinational enterprises. Accordingly, already existing firms located within the CEE economies but which are owned by foreign firms tended to grow by approximately 3.5 percentage points faster. This finding could be either driven by cherry-picking strategies of the foreign investors or by the positive impact of foreign control on firm performance.

Focusing on the results for business barriers we obtain some interesting and heterogeneous results. The results in column (1) of Table 1 indicates that the overall level of institutional quality has a very small and statistically insignificant negative impact on a firm's intensive margin growth performance. Column (2), however, indicates that once one distinguishes between institutional regulations and the remaining overall barriers 
for doing business, the overall effect turns out to be relatively large, negative and statistically significant. By contrast, an increase in institutional barriers for doing business (for example from major to moderate obstacle to doing business) tends to increase job creation by existing firms. This positive effect is of a similar magnitude as the negative overall effect and, thus, both of them are offsetting each other in column (1). From Table S1 in the Additional file 1 one can infer that institutional business barriers, as defined by the survey questions used to measure it, can also be viewed as barriers for market entry. Accordingly, the positive effect of institutional barriers is well in line with the expectation that already active firms profit from an increase in entry costs. From column (3) we are able to infer that access to finance is crucial for firm growth. An increase in the difficulty to raise financial resources substantially decreases intensive margin job creation by surviving firms located at the CEE economies ${ }^{14}$. In a similar vein, restrictive business taxation rules correlate negatively with employment growth in existing firms. In industries with complex tax systems, employment growth rates were reduced by 2.0 percentage points on average (Table 1, column 7). By contrast, crime, corruption and labor market regulations do not affect the average firm growth performance of surviving CEE firms significantly during the time span from 2002 to $2009^{15}$.

It should be noted that, in addition to directly reducing the intensive margin growth rate of employment, an unfriendly business environment is negatively associated with firm productivity in the period 2002-2008. The parameter estimate from a bivariate regression of TFP on the overall measure of institutional barriers is -0.2 , while in terms of growth rates, the relationship between the employment growth and the TFP growth among the firms in our sample was positive prior to 2008, but statistically insignificant ${ }^{16}$.

In Table 2, we report the estimation results of repeating our exercise for the crisis year 2009. The global financial crisis is known to have affected asymmetrically firms operating in different industries in CEE countries, with the construction and manufacturing industries showing the largest intensive margin job losses (see Figure 2). When controlling for other factors and in comparison to firms operating in other industries, surviving construction and manufacturing firms reduced their employment growth on average by 3.1 to 7.4 percentage points more than the rest of the firms (see Table 2). In a similar vein and with the exception of the specification without any business barriers, agricultural and fishing firms are also substantially affected by the crisis with a relative average intensive margin job creation rate of around -5.0 percentage points. In contrast, the surveyed firms operating in the services sector were the least affected by the global recession. Overall, existing firms that operated in mining and utilities industries tended to suffer less from the financial crisis.

During the global financial crisis, firm size and age were negatively correlated with intensive margin job creation, while more productive firms exhibited higher employment growth rates. One percent larger and older firms showed job creation rates that were on average approximately 7.5 and 5.4 percentage points lower than for the rest of the surveyed firms. A one percent increase in TFP, by contrast, enabled on average about 3.9 percentage points higher intensive margin employment growth. Moreover, productivity differentials were more crucial for job creation among the surveyed firms during the economic crisis than during the preceding years. Firms that are controlled by foreign owners were also able to perform relatively well. Accordingly, the average 
employment growth rate in existing subsidiaries of multinational corporate groups exceeded that in domestically controlled firms by approximately 4.0 percentage points.

Perceived institutional barriers and regulations do not appear to correlate with intensive margin job creation in CEE economies during the financial crisis. The parameter estimates for all different specifications and types of business barriers are negative throughout but none of these effects is statistically significant. One potential reason for this result is that business regulations might not affect firm growth in the short run and, therefore, one would need data for a longer post-crisis period in order to accurately estimate the overall impact of institutional regulations during periods of crises. Another reason could be that only some specific types of firms are affected by the financial crisis and the estimation of average effects might hide some important heterogeneity in the response of firms to institutional regulations.

The model given by equations (1) and (2) (as most specifications in the empirical firm growth literature) has the implicit assumption that the effect of covariates on firm growth does not depend on the relative performance of the firm considered. Such a characteristic of the specification implies that we cannot infer anything about the potential differences in the effect of institutional barriers on intensive margin job creation depending on the employment growth performance of the enterprise. To give an example, the results from Table 1 could be driven by managers of slow growing firms blaming institutional barriers more frequently than more successful competitors leading to a potential reverse causality issue.

In order to address such a question, we use quantile regression methods, which are able to account for differences in the model parameters across quantiles of the distribution of the intensive margin firm growth variable. Quantile regression specifications (see Koenker and Bassett 1978, for the seminal publication providing the asymptotic theory or Koenker and Hallock 2001, for a survey on the use of quantile regressions in economics) aim at modeling directly conditional quantile functions, where the independent variables are assumed to affect the quantiles of the conditional distribution of the dependent variable.

In our modeling framework, the quantile regression specification is given by

$$
\begin{aligned}
& g_{i j}=\alpha+\pi_{i j \theta} S_{0 i j}+\boldsymbol{x}_{i j} \boldsymbol{\gamma}_{\boldsymbol{\theta}}+\boldsymbol{z}_{j} \boldsymbol{\delta}_{\theta}+\varepsilon_{\theta i}, \\
& \pi_{i j \theta}=\beta_{0 \theta}+\beta_{1 \theta} A_{i j},
\end{aligned}
$$

where parameter vectors with a $\theta$ subindex are associated with the corresponding $\theta$-th quantile. ${ }^{17}$ The quantile regression estimator of the parameters of interest is obtained by minimizing the weighted sum of absolute errors, where the weights depend on the quantile considered, and can be interpreted as the change in the $\theta$-th conditional quantile of the dependent variable due to a (marginal) change in the corresponding covariate.

The results of the quantile regression for the period 2002-2008 are presented in Table 3 for a specification using the overall index of perceived institutional barriers ${ }^{18}$. We report results for the 10th, 25th, 50th, 75th and 90th conditional percentiles of the distribution of intensive margin job creation. The estimated parameters for the firmspecific variables are qualitatively similar to those found in the standard regression 
Table 3 Quantile regression results, 2002-2008

\begin{tabular}{|c|c|c|c|c|c|}
\hline Variables & $\begin{array}{l}\text { 10th-percentile } \\
\text { (1) }\end{array}$ & $\begin{array}{l}\text { 1st quartile } \\
\text { (2) }\end{array}$ & $\begin{array}{l}\text { Median } \\
\text { (3) }\end{array}$ & $\begin{array}{l}\text { 3rd quartile } \\
\text { (4) }\end{array}$ & $\begin{array}{l}\text { 90th-percentile } \\
\text { (5) }\end{array}$ \\
\hline \multicolumn{6}{|c|}{ Firm characteristics } \\
\hline \multirow[t]{2}{*}{ Initial size } & $-0.129 * * *$ & $-0.051^{* * *}$ & $-0.028^{* * *}$ & $-0.088^{* * *}$ & $-0.099^{* * *}$ \\
\hline & $(0.008)$ & $(0.003)$ & $(0.007)$ & $(0.004)$ & $(0.004)$ \\
\hline \multirow[t]{2}{*}{ Age } & $-0.076^{* * *}$ & $-0.034^{* * *}$ & $-0.040^{* * *}$ & $-0.101^{* * *}$ & $-0.109^{* * *}$ \\
\hline & $(0.007)$ & $(0.003)$ & $(0.008)$ & $(0.005)$ & $(0.005)$ \\
\hline \multirow[t]{2}{*}{ Initial size $\times$ age } & $0.027^{* * *}$ & $0.006^{* * *}$ & 0.004 & $0.019^{* * *}$ & $0.019^{* * *}$ \\
\hline & $(0.003)$ & $(0.001)$ & $(0.002)$ & $(0.002)$ & $(0.001)$ \\
\hline \multirow[t]{2}{*}{ TFP } & $0.011^{* * *}$ & $0.007^{* * *}$ & $0.008^{* * *}$ & $0.018^{* * *}$ & $0.023^{* * *}$ \\
\hline & $(0.002)$ & $(0.001)$ & $(0.001)$ & $(0.002)$ & $(0.002)$ \\
\hline \multirow[t]{2}{*}{ Foreign owner } & $0.024^{* * *}$ & $0.028^{* * *}$ & $0.021^{* * *}$ & $0.036^{* * *}$ & $0.045^{* * *}$ \\
\hline & $(0.008)$ & $(0.004)$ & $(0.003)$ & $(0.005)$ & $(0.008)$ \\
\hline \multicolumn{6}{|c|}{ Industry characteristics } \\
\hline \multirow[t]{2}{*}{ Agriculture } & $0.049^{* *}$ & $0.029^{* *}$ & $0.036^{* * * *}$ & $0.032^{*}$ & -0.026 \\
\hline & $(0.022)$ & $(0.017)$ & $(0.013)$ & $(0.018)$ & $(0.038)$ \\
\hline \multirow[t]{2}{*}{ Construction } & $0.043^{* * *}$ & $0.026^{* *}$ & $0.043^{* * *}$ & $0.067^{* * *}$ & 0.058 \\
\hline & $(0.016)$ & $(0.012)$ & $(0.007)$ & $(0.014)$ & $(0.036)$ \\
\hline \multirow[t]{2}{*}{ Manufacturing } & $0.045^{* * *}$ & $0.025^{* *}$ & $0.029^{* * *}$ & $0.041^{* * *}$ & 0.008 \\
\hline & $(0.015)$ & $(0.012)$ & $(0.007)$ & $(0.013)$ & $(0.035)$ \\
\hline \multirow[t]{2}{*}{ Wholesale } & 0.018 & 0.008 & $0.014^{* *}$ & 0.017 & -0.016 \\
\hline & $(0.015)$ & $(0.012)$ & $(0.006)$ & $(0.013)$ & $(0.035)$ \\
\hline \multirow[t]{2}{*}{ Transport } & 0.015 & 0.008 & $0.018^{* * *}$ & $0.028^{* *}$ & -0.002 \\
\hline & $(0.017)$ & $(0.011)$ & $(0.006)$ & $(0.013)$ & $(0.036)$ \\
\hline \multirow[t]{2}{*}{ Overall inst. } & 0.014 & -0.003 & $-0.010^{* *}$ & $-0.021^{* * *}$ & $-0.030^{* * *}$ \\
\hline & $(0.012)$ & $(0.006)$ & $(0.004)$ & $(0.006)$ & $(0.009)$ \\
\hline \multicolumn{6}{|l|}{ Fixed effects } \\
\hline Country & $91.90^{* * *}$ & $107.61^{* * *}$ & $23.47^{* * *}$ & $49.35^{* * *}$ & $40.83^{* * *}$ \\
\hline Pseudo $R^{2}$ & 0.098 & 0.079 & 0.009 & 0.096 & 0.137 \\
\hline Observations & 34,068 & 34,068 & 34,068 & 34,068 & 34,068 \\
\hline
\end{tabular}

Notes: The dependent variable is the average annual employment growth rate for the period 2002-2008. Quantile regression estimates. Constant not reported. Bootstrapped standard errors in parenthesis. ${ }^{*},{ }^{* *}$ and ${ }^{* * *}$ denote significance at 10 percent, 5 percent and 1 percent levels, respectively. The coefficient for the number of observed years is not reported.

models presented in Table 1 and the quantitative insights are comparable to those obtained using the linear regression model. Given the fact that intensive margin firm growth in our sample is not evenly distributed across sectors, it is not surprising that parameters attached to the industry dummies differ across quantiles.

The most interesting results of the quantile regression estimates are those related to the effect of institutional barriers on intensive margin job creation. The insignificant effect found in the linear regression model reported in Table 1 appears to be driven by the worst performing firms. By contrast, the effect is much stronger and significant in the highest quantiles and the size of such negative job creation effects appears to be monotonically increasing as we move from lower to higher percentiles of the (conditional) distribution. Figure 4 shows the parameter estimates corresponding to the variable measuring institutional barriers for a finer quantile grid than that in Table 3, together with their 95\% 


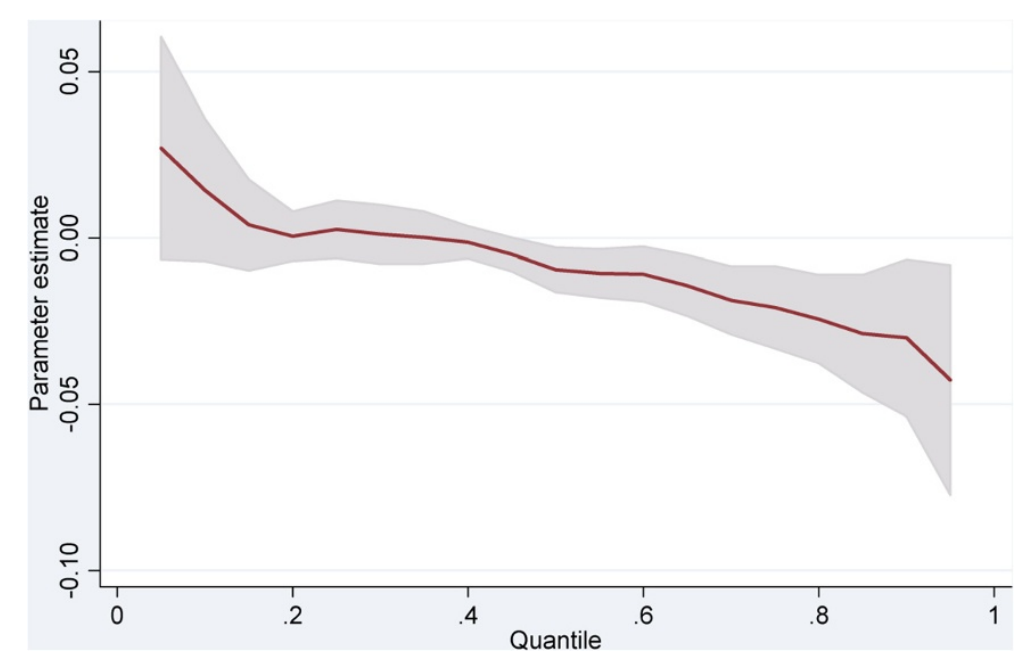

Figure 4 Effect of institutional barriers on employment growth by quantile with bootstrap $95 \%$ confidence intervals, 2002-2008.

confidence interval ${ }^{19}$, and confirms this conclusion. The negative effect appears significant for quantiles above the median and the structure of the effects depicted in Figure 4 provides robust evidence concerning the fact that it is the best performing firms in terms of intensive margin job creation that have suffered most from the institutional setting in the CEE region. Figure 4 reveals that the most successful surviving firms are harmed in their employment growth performance (i.e., they would have experienced even larger job creation rates) while poor performing firms are not affected by institutional regulations. This finding contradicts the above mentioned view, that the so far obtained results are driven by poor performing firms complaining about business barriers.

\section{Institutional barriers and gazelles in central and eastern Europe}

High-growth firms, usually known as gazelles in the literature, are relatively rare in the CEE region but essential for providing new jobs in this group of countries. Arias et al. (2013) reveals evidence that net job creation at the intensive margin in the region has typically been led by a handful of firms, many of them young enterprises. On average, about 10-15 percent of all firms accounted for over two-thirds of net job creation in the Europe and Central Asia region in the years leading to the crisis, and this pattern holds regardless of whether the entire enterprise sector is experiencing net job creation or net job destruction ${ }^{20}$. The results of the analysis carried out hitherto reveals that the intensive margin job creation potential of this group of high-growth firms is particularly affected by institutional barriers in the region. In this section we carry out a detailed analysis of how perceived institutional differences across sectors affect the likelihood of such gazelles emerging. Given the importance of this group of highgrowth enterprises, such a step appears necessary to understand the full extent of the effect of institutions on intensive margin job creation in CEE economies.

OECD (2009) defines gazelles as firms that are: (i) younger than 5 years; (ii) initially employ more than 10 workers; and (iii) experienced annual employment growth rates of (at least) 20 percent during 3 consecutive years. Given the focus of the current analysis on the distribution of high growth firms across different firm size and firm age 
cohorts, we identify gazelles in our sample using exclusively the third part of the definition (i.e., the 20 percent tri-annual growth performance during the time period from 2006 to 2008). In order to compare pre- and post-crisis gazelle probabilities we focus on the years from 2006 to 2008 and 2009, respectively. With the data at hand we can also use the time period from 2003 to 2005 for measuring gazelles. As a robustness analysis we discuss the main findings from probit regressions for gazelles observed from 2003 to 2005 in endnote 22. The share of high-growth firms and the share of intensive margin jobs created by these are presented in Figure 5. The share of highgrowth firms relative to all surveyed firms with positive employment growth was around 3.5 percent in the years prior to the global financial crisis. It was by far largest in Bulgaria, where approximately 7.4 percent of all net job creating firms were gazelles. High-growth firms were most important in Romania and Bulgaria with corresponding intensive margin net job creation shares exceeding 12.6 percent. In addition to Hungary and Slovakia, the role of existing high-growth firms for overall job creation was negligible in the Czech Republic and Poland.

To unveil the determinants of the probability of being a gazelle and measuring the effect of institutional barriers, standard probit regressions are estimated using our sample of firms. The probability to be a high-growth firm is modeled as a function of the same industry and firm-specific characteristics as in the regressions presented in Section 3. The only exception is that, in this exercise, an interaction effect of firm size with firm age is not included ${ }^{21}$. Formally, the model is given by

$$
\operatorname{Pr}\left(H G_{i j}=1 \mid \boldsymbol{x}_{i j}, \boldsymbol{z}_{j}\right)=\boldsymbol{\Phi}\left(\boldsymbol{\tau}+\boldsymbol{x}_{i j} \boldsymbol{\mu}+\boldsymbol{z}_{j} \boldsymbol{\lambda}\right),
$$

where $H G_{i j}=1$ if firm $i$ in industry $j$ is a high-growth firm and $H G_{i j}=0$ otherwise. The vector $\boldsymbol{x}_{i j}$ includes all firm-specific characteristics, $z_{j}$ comprises industry-level information; $\boldsymbol{\mu}$ are $\lambda$ are vectors of parameters to be estimated and $\boldsymbol{\Phi}(\cdot)$ denotes the cumulative distribution function (CDF) of the normal distribution. As in the regression models in

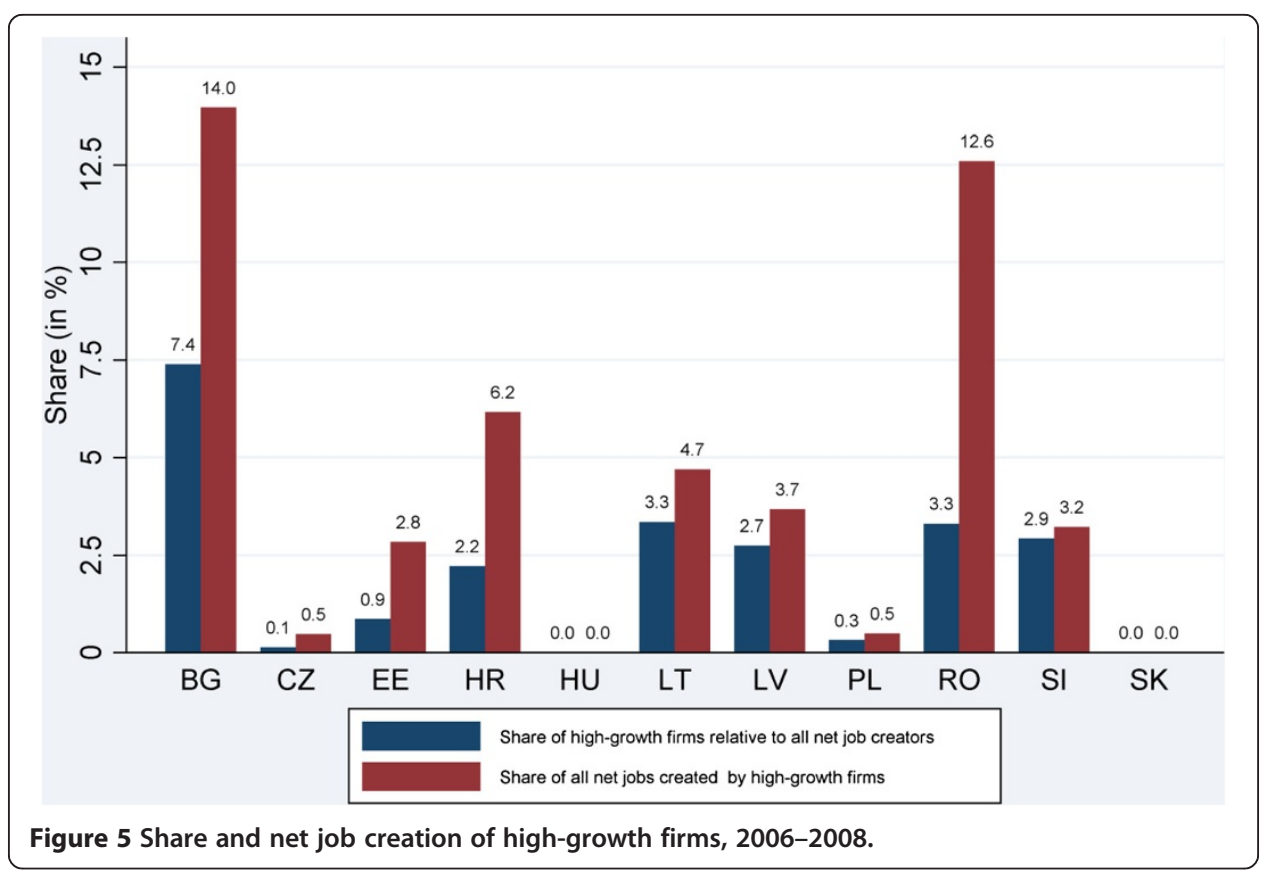


Section 3, the covariates of interest (collected in $\boldsymbol{x}_{\boldsymbol{i}}$ and $\boldsymbol{z}_{j}$ ) include the initial firm size, firm age, TFP, foreign ownership, institutional business barriers and industry dummy variables. They are all measured in 2005. Given the lack of observations of high-growth firms in Hungary and Slovakia, the specification for the boom years from 2006 to 2008 does not include country-fixed effects. The model is re-estimated to examine a firm's probability of belonging to the group of high-growth enterprises after the crisis, using the same model specifications and covariates. In this case, the probability to grow with more than 20 percent in 2009 is explained by the same covariates as in the pre-crisis period, but measured in 2008. The perceived institutional barriers for doing business are in this case taken from the 2009 survey and the specification controls for fixed effects at the country level.

The results of the probit estimations can be found in Table 4 for the 2006-2008 period and in Table 5 for the 2008-2009 period. In the pre-crisis period, the probability of being an existing high-growth firm was largest in the construction, manufacturing, transport and communications industries. In comparison to the other services sector, construction firms were between 2 and 7.3 percentage points more likely to grow with more than 20 percent annually in each year from 2006 to 2008. Moreover, and again in comparison to the other services industries sector, agricultural and fishing industries as well as firms operating in the wholesale trade and retailing or providers of restaurant and hotel services were also around 2 percentage points more likely to be high-growth firms. This result again confirms our discussion from above, namely that more traditional firms tend to grow faster at the intensive margin while job creation by service firms seems to be driven by firm entry which we cannot incorporate in this analysis.

Prior to the crisis, smaller and younger continuing firms were more likely to be highgrowth firms. Among the surveyed firms, an increase in firm size or firm age by 1 percent affected negatively the average probability to grow by more than 20 percent annually from 2006 to 2008 by 0.1 to 0.5 and 0.8 to 1.4 percentage points, respectively. The latter result is consistent with the documented crucial role of young firms for the overall job creation prior to the crisis. High total factor productivity was associated with a higher probability of being a high-growth surviving firm prior to the crisis. More precisely, an increase in a firm's TFP by 10 percent was associated with a higher probability to be a Gazelle by about 1 to 2 percentage points. While productivity remained one critical predictor of job creation among the surveyed firms, in quantitative terms firm size and age were better predictors. Subsidiaries of multinational corporate groups are also more likely to be gazelles with the quantitative effect being similar to the one for firm size. Again, this finding might reflect the selection of the most successful firms by foreign owners or by superior market strategies induced by foreign ownership.

Table 4 shows that the overall institutional barriers and regulations correlated negatively with the probability of being a high-growth firm prior to the crisis. This is true for the overall institutional regulation measure reported on column (2) and all other overall measures that leave out the individual restriction mentioned in columns (3) to (8). To give an example, a one-unit increase in the perceived overall business friendliness by the surveyed CEE firms increased the probability for high-growth by 2.4 percentage points. However, Table 4 also points to the heterogeneous individual effects of specific barriers. In line with our discussion from Section 3 an increase in the institutional regulations reduces the negative effect of all other business barriers indicating 
Table 4 Estimation results, probit model for the probability of being a high-growth firm, 2006-2008

\begin{tabular}{|c|c|c|c|c|c|c|c|c|}
\hline Variables & $\begin{array}{l}\text { No regulations } \\
\text { (1) }\end{array}$ & $\begin{array}{l}\text { Overall } \\
(2)\end{array}$ & $\begin{array}{l}\text { Institutions } \\
\text { (3) }\end{array}$ & $\begin{array}{l}\text { Finance } \\
\text { (4) }\end{array}$ & $\begin{array}{l}\text { Crime } \\
(5)\end{array}$ & $\begin{array}{l}\text { Corruption } \\
(6)\end{array}$ & $\begin{array}{l}\operatorname{Tax} \\
(7)\end{array}$ & $\begin{array}{l}\text { Labor } \\
(8)\end{array}$ \\
\hline \multicolumn{9}{|c|}{ Firm characteristics } \\
\hline \multirow[t]{2}{*}{ Initial size } & $-0.001^{* *}$ & $-0.005^{* * *}$ & $-0.005^{* * *}$ & $-0.005^{* * *}$ & $-0.005^{* * *}$ & $-0.005^{* * *}$ & $-0.005^{* * *}$ & $-0.005^{* * *}$ \\
\hline & $(0.001)$ & $(0.000)$ & $(0.000)$ & $(0.000)$ & $(0.000)$ & $(0.000)$ & $(0.000)$ & $(0.000)$ \\
\hline \multirow[t]{2}{*}{ Age } & $-0.008^{* * *}$ & $-0.014^{* * *}$ & $-0.014^{* * *}$ & $-0.014^{* * *}$ & $-0.014^{* * *}$ & $-0.013^{* * *}$ & $-0.014^{* * *}$ & $-0.014^{* * *}$ \\
\hline & $(0.001)$ & $(0.000)$ & $(0.000)$ & $(0.000)$ & $(0.000)$ & $(0.000)$ & $(0.000)$ & $(0.000)$ \\
\hline \multirow[t]{2}{*}{ TFP } & - & $0.001^{* * *}$ & $0.001^{* * *}$ & $0.001^{* * *}$ & $0.001^{* * *}$ & $0.002^{* * *}$ & $0.001^{* * *}$ & $0.001^{* * *}$ \\
\hline & - & $(0.000)$ & $(0.000)$ & $(0.000)$ & $(0.000)$ & $(0.000)$ & $(0.000)$ & $(0.000)$ \\
\hline \multirow[t]{2}{*}{ Foreign owner } & & $0.004^{* * *}$ & $0.005^{* * *}$ & $0.004^{* * *}$ & $0.004^{* * *}$ & $0.004^{* * *}$ & $0.005^{* * *}$ & $0.004^{* * *}$ \\
\hline & & $(0.001)$ & $(0.002)$ & $(0.001)$ & $(0.001)$ & $(0.001)$ & $(0.001)$ & $(0.001)$ \\
\hline \multicolumn{9}{|c|}{ Industry characteristics } \\
\hline \multirow[t]{2}{*}{ Agriculture } & 0.001 & $0.021^{* * *}$ & $0.007^{* * *}$ & $0.014^{* * *}$ & $0.023^{* * *}$ & $0.031^{* * *}$ & $0.018^{* * *}$ & $0.020^{* * *}$ \\
\hline & $(0.002)$ & $(0.001)$ & $(0.002)$ & $(0.002)$ & $(0.001)$ & $(0.001)$ & $(0.001)$ & $(0.001)$ \\
\hline \multirow[t]{2}{*}{ Mining } & $0.010^{*}$ & - & - & - & - & - & - & - \\
\hline & $(0.005)$ & - & - & - & - & - & - & - \\
\hline \multirow[t]{2}{*}{ Construction } & $0.020^{* * *}$ & $0.063^{* * *}$ & $0.043^{* * *}$ & $0.054^{* * *}$ & $0.065^{* * *}$ & $0.073^{* * *}$ & $0.059^{* * *}$ & $0.063^{* * *}$ \\
\hline & $(0.002)$ & $(0.003)$ & $(0.004)$ & $(0.004)$ & $(0.003)$ & $(0.003)$ & $(0.003)$ & $(0.003)$ \\
\hline \multirow[t]{2}{*}{ Manufacturing } & $0.006^{* *}$ & $0.038^{* * *}$ & $0.022^{* * *}$ & $0.034^{* * *}$ & $0.044^{* * *}$ & $0.055^{* * *}$ & $0.034^{* * *}$ & $0.035^{* * *}$ \\
\hline & $(0.003)$ & $(0.002)$ & $(0.002)$ & $(0.002)$ & $(0.002)$ & $(0.002)$ & $(0.002)$ & $(0.002)$ \\
\hline \multirow[t]{2}{*}{ Wholesale } & 0.005 & $0.026^{* * *}$ & $0.018^{* * *}$ & $0.022^{* * *}$ & $0.025^{* * *}$ & $0.036^{* * *}$ & $0.023^{* * *}$ & $0.024^{* * *}$ \\
\hline & $(0.003)$ & $(0.001)$ & $(0.002)$ & $(0.001)$ & $(0.001)$ & $(0.001)$ & $(0.002)$ & $(0.001)$ \\
\hline \multirow[t]{2}{*}{ Transport } & $0.012^{* * *}$ & $0.053^{* * *}$ & $0.036^{* * *}$ & $0.049^{* * *}$ & $0.060^{* * *}$ & $0.076^{* * *}$ & $0.049^{* * *}$ & $0.050^{* * *}$ \\
\hline & $(0.004)$ & $(0.001)$ & $(0.003)$ & $(0.002)$ & $(0.003)$ & $(0.005)$ & $(0.001)$ & $(0.001)$ \\
\hline
\end{tabular}


Table 4 Estimation results, probit model for the probability of being a high-growth firm, 2006-2008 (Continued)

\begin{tabular}{|c|c|c|c|c|c|c|c|c|}
\hline \multirow[t]{2}{*}{ Overall inst.a) } & - & $-0.023^{* * *}$ & $-0.029^{* * *}$ & $-0.016^{* * *}$ & $-0.032^{* * *}$ & $-0.052^{* * *}$ & $-0.017^{* * *}$ & $-0.014^{* * *}$ \\
\hline & - & $(0.001)$ & $(0.002)$ & $(0.002)$ & $(0.002)$ & $(0.002)$ & $(0.001)$ & $(0.001)$ \\
\hline \multirow[t]{2}{*}{ Inst. regulation } & - & - & $0.005^{* * *}$ & - & - & - & - & - \\
\hline & - & - & $(0.001)$ & - & - & - & - & - \\
\hline \multirow[t]{2}{*}{ Access to finance } & - & - & - & $-0.007^{* * *}$ & - & - & - & - \\
\hline & - & - & - & $(0.002)$ & - & - & - & - \\
\hline \multirow[t]{2}{*}{ Crime } & - & - & - & - & $0.009^{* * *}$ & - & - & - \\
\hline & - & - & - & - & $(0.003)$ & - & - & - \\
\hline \multirow[t]{2}{*}{ Corruption } & - & - & - & - & - & $0.024^{* * *}$ & - & - \\
\hline & - & - & - & - & - & $(0.002)$ & - & - \\
\hline \multirow[t]{2}{*}{ Taxation } & - & - & - & - & - & - & $-0.006^{* * *}$ & - \\
\hline & - & - & - & - & - & - & $(0.001)$ & \\
\hline \multirow[t]{2}{*}{ Labor regulations } & - & - & - & - & - & - & - & $-0.010^{* * *}$ \\
\hline & - & - & - & - & - & - & - & $(0.001)$ \\
\hline Pseudo $R^{2}$ & 0.034 & 0.052 & 0.053 & 0.052 & 0.052 & 0.061 & 0.052 & 0.052 \\
\hline Observations & 196,653 & 45,392 & 45,392 & 45,392 & 45,392 & 45,392 & 45,392 & 45,392 \\
\hline
\end{tabular}

Notes: Constant not reported. Clustered standard errors (at the 2-digit industry level) in parenthesis. Average marginal effects reported (see, e.g. Bartus 2005)*** and *** denote significance at 10 percent, 5 percent and 1 percent levels, respectively. Wald tests for country-fixed effects not reported. ${ }^{\text {a) }}$ In columns (3)-(8) the overall institutional barriers are calculated without including the questions on the respective specific institutional barrier investigated. 
Table 5 Estimation results, probit model for the probability of being a high-growth firm, 2008-2009

\begin{tabular}{|c|c|c|c|c|c|c|c|c|}
\hline Variables & $\begin{array}{l}\text { No regulations } \\
\text { (1) }\end{array}$ & $\begin{array}{l}\text { Overall } \\
(2)\end{array}$ & $\begin{array}{l}\text { Institutions } \\
\text { (3) }\end{array}$ & $\begin{array}{l}\text { Finance } \\
\text { (4) }\end{array}$ & $\begin{array}{l}\text { Crime } \\
(5)\end{array}$ & $\begin{array}{l}\text { Corruption } \\
(6)\end{array}$ & $\begin{array}{l}\operatorname{Tax} \\
(7)\end{array}$ & $\begin{array}{l}\text { Labor } \\
(8)\end{array}$ \\
\hline \multicolumn{9}{|c|}{ Firm characteristics } \\
\hline \multirow[t]{2}{*}{ Initial size } & $-0.023^{* * *}$ & $-0.043^{* * *}$ & $-0.043^{* * *}$ & $-0.043^{* * *}$ & $-0.043^{* * *}$ & $-0.043^{* * *}$ & $-0.043^{* * *}$ & $-0.043^{* * *}$ \\
\hline & $(0.000)$ & $(0.000)$ & $(0.000)$ & $(0.000)$ & $(0.000)$ & $(0.000)$ & $(0.000)$ & $(0.000)$ \\
\hline \multirow[t]{2}{*}{ Age } & $-0.029^{* * *}$ & $-0.036^{* * *}$ & $-0.036^{* * *}$ & $-0.036^{* * *}$ & $-0.036^{* * *}$ & $-0.036^{* * *}$ & $-0.036^{* * *}$ & $-0.036^{* * *}$ \\
\hline & $(0.000)$ & $(0.000)$ & $(0.000)$ & $(0.000)$ & $(0.000)$ & $(0.000)$ & $(0.000)$ & $(0.000)$ \\
\hline \multirow[t]{2}{*}{ TFP } & - & $0.003^{* * *}$ & $0.003^{* * *}$ & $0.003^{* * *}$ & $0.003^{* * *}$ & $0.003^{* * *}$ & $0.003^{* * *}$ & $0.003^{* * *}$ \\
\hline & - & $(0.000)$ & $(0.000)$ & $(0.000)$ & $(0.000)$ & $(0.000)$ & $(0.000)$ & $(0.000)$ \\
\hline \multirow[t]{2}{*}{ Foreign owner } & & $0.035^{* * *}$ & $0.034^{* * *}$ & $0.035^{* * *}$ & $0.035^{* * *}$ & $0.035^{* * *}$ & $0.035^{* * *}$ & $0.035^{* * *}$ \\
\hline & & $(0.001)$ & $(0.001)$ & $(0.001)$ & $(0.001)$ & $(0.001)$ & $(0.001)$ & $(0.001)$ \\
\hline \multicolumn{9}{|c|}{ Industry characteristics } \\
\hline \multirow[t]{2}{*}{ Agriculture } & $0.051^{* * *}$ & $0.041^{* * *}$ & $0.040^{* * *}$ & $0.041^{* * *}$ & $0.046^{* * *}$ & $0.051^{* * *}$ & $0.038^{* * *}$ & $0.042^{* * *}$ \\
\hline & $(0.003)$ & $(0.001)$ & $(0.001)$ & $(0.001)$ & $(0.001)$ & $(0.002)$ & $(0.001)$ & $(0.001)$ \\
\hline \multirow[t]{2}{*}{ Mining } & $0.025^{* * *}$ & - & - & - & - & - & - & - \\
\hline & $(0.005)$ & - & - & - & - & - & - & - \\
\hline \multirow[t]{2}{*}{ Construction } & $0.018^{* * *}$ & $0.009^{* * *}$ & $0.008^{* * *}$ & $0.009^{* * *}$ & $0.010^{* * *}$ & $0.019^{* * *}$ & $0.007^{* * *}$ & $0.010^{* * *}$ \\
\hline & $(0.003)$ & $(0.001)$ & $(0.001)$ & $(0.001)$ & $(0.001)$ & $(0.002)$ & $(0.001)$ & $(0.001)$ \\
\hline \multirow[t]{2}{*}{ Manufacturing } & -0.001 & $-0.014^{* * *}$ & $-0.015^{* * *}$ & $-0.014^{* * *}$ & $-0.009^{* * *}$ & $-0.012^{* * *}$ & $-0.016^{* * *}$ & $-0.013^{* * *}$ \\
\hline & $(0.003)$ & $(0.002)$ & $(0.002)$ & $(0.002)$ & $(0.002)$ & $(0.002)$ & $(0.002)$ & $(0.002)$ \\
\hline \multirow[t]{2}{*}{ Wholesale } & $0.011^{* * *}$ & $-0.005^{* *}$ & $-0.007^{* * *}$ & $-0.005^{* * *}$ & $-0.004^{* * *}$ & -0.001 & $-0.007^{* * *}$ & $-0.005^{* * *}$ \\
\hline & $(0.001)$ & $(0.002)$ & $(0.001)$ & $(0.001)$ & $(0.001)$ & $(0.001)$ & $(0.001)$ & $(0.001)$ \\
\hline \multirow[t]{2}{*}{ Transport } & $0.015^{* * *}$ & 0.000 & $-0.002^{* * *}$ & 0.000 & 0.000 & $0.002^{* * *}$ & -0.001 & -0.001 \\
\hline & $(0.003)$ & $(0.001)$ & $(0.001)$ & $(0.001)$ & $(0.001)$ & $(0.001)$ & $(0.001)$ & $(0.001)$ \\
\hline
\end{tabular}


Table 5 Estimation results, probit model for the probability of being a high-growth firm, 2008-2009 (Continued)

\begin{tabular}{|c|c|c|c|c|c|c|c|c|}
\hline \multirow[t]{2}{*}{ Overall inst.a) } & - & $-0.006^{* * *}$ & $-0.009^{* * *}$ & $-0.006^{* * *}$ & $-0.013^{* * *}$ & $-0.006^{* * *}$ & $-0.006^{* * *}$ & $-0.006^{* * *}$ \\
\hline & - & $(0.001)$ & $(0.001)$ & $(0.001)$ & $(0.002)$ & $(0.001)$ & $(0.001)$ & $(0.001)$ \\
\hline \multirow[t]{2}{*}{ Inst. regulation } & - & - & -0.000 & - & - & - & - & - \\
\hline & - & - & $(0.001)$ & - & - & - & - & - \\
\hline \multirow[t]{2}{*}{ Access to finance } & - & - & - & -0.001 & - & - & - & - \\
\hline & - & - & - & $(0.001)$ & - & - & - & - \\
\hline \multirow[t]{2}{*}{ Crime } & - & - & - & - & $0.009^{* * *}$ & - & - & - \\
\hline & - & - & - & - & $(0.002)$ & - & - & - \\
\hline \multirow[t]{2}{*}{ Corruption } & - & - & - & - & - & $-0.014^{* * *}$ & - & - \\
\hline & - & - & - & - & - & $(0.002)$ & - & - \\
\hline \multirow[t]{2}{*}{ Taxation } & - & - & - & - & - & - & $0.002^{* * *}$ & - \\
\hline & - & - & - & - & - & - & $(0.001)$ & - \\
\hline \multirow[t]{2}{*}{ Labor regulations } & - & - & - & - & - & - & - & $-0.004^{* * *}$ \\
\hline & - & - & - & - & - & - & - & $(0.001)$ \\
\hline Pseudo $R^{2}$ & 0.031 & 0.052 & 0.052 & 0.052 & 0.052 & 0.052 & 0.052 & 0.052 \\
\hline Observations & 299,695 & 79,827 & 79,882 & 79,836 & 79,827 & 79,827 & 79,827 & 79,827 \\
\hline
\end{tabular}

Notes: Constant not reported. Clustered standard errors (at the 2-digit industry level) in parenthesis. Average marginal effects reported (see, e.g., Bartus 2005) * ** and *** denote significance at 10 percent, 5 percen and 1 percent levels, respectively. Wald tests for country-fixed effects not reported. ${ }^{\text {a) }}$ In columns (3)-(8) the overall institutional barriers are calculated without including the questions on the respective specific institutional barrier investigated. 
that existing firms operating in highly regulated markets are more likely to grow very fast. In a similar vein, crime and corruption also seems to increase the likelihood of the presence of high-growth firms. This result might reflect perceptions of less successful firms, whose owners might argue that their high-growth competitors profit from corruption and crime in order to be so successful.

By contrast, we are also able to estimate some negative effects of business barriers for the probability to observe gazelles. In this regard, regulations related to the labor markets and financial restrictions correlated most negatively with the occurrence of being a high-growth firm. In a similar vein, the tax system also seemed to be a crucial predictor for high-growth firms ${ }^{22}$.

The results for the crisis period, presented in Table 5, indicate that firm-specific determinants for high-growth firms are crucially important to explain why some existing firms become gazelles in CEE countries. In 2009, firm size, age, productivity and foreign ownership were important restrictions to becoming a high growth firms. A one percent increase in size and age reduced a firm's probability of growing more than 20 percent by approximately 2.3 to 4.3 and 2.9 to 3.6 percentage points, on average. A 10 percent increase in TFP, by contrast, increased the probability of being a gazelle by 3 percentage points. Foreign owned surviving firms were also more likely to be gazelles with the corresponding average marginal effect amounting to 3.5 percentage points. These findings, once more, highlight the importance of small, young, productive and foreign owned firms for the creation of new jobs at the intensive margin in CEE economies. Surveyed firms in manufacturing and wholesaler, retail trader, hotels and restaurants were most severely affected by the economic downturn and were the least likely to be high-growth firms during the global financial crisis. In contrast, the probability of becoming a high-growth firm among the surveyed firms in farming, fishing was positively affected by the economic crisis. Fast-growing surviving firms in these sectors, however, comprised a very small portion of the high-growth firms in the region, given the small size of the agricultural and fishing industries. Accordingly, the positive and significant marginal effects reflect only a very small number of gazelles. Firms operating in the construction sector also exhibited a relatively high probability of being fastgrowing firms. Coupled with the firm-growth results from above (i.e., that on average, firms in this sector performed relatively poorly during the financial crisis), the regression results suggest that intensive margin job creation during the crisis in the construction sector was mostly driven by the best performing firms. The increase in public demand for construction activities induced by governmental investment and EU-supported programs that aimed to mitigate the negative employment effects of the financial crisis may explain such a result.

After 2008, some barriers for doing business are still found to be responsible for depressing the likelihood of becoming a high-growth firm. A one unit decrease in the overall institutional barriers perceived by the surveyed firms was associated with a 0.6 percentage point increase in the probability to be a high-growth firm (Table 5, column 2). Similar qualitative and quantitative effects were obtained for corruption and labor regulations. Tax related barriers for doing business and crime are found to positively affect the high-growth probability.

To sum up, our empirical exercise reveals that the standard OLS estimations as well as the quantile regressions and the probit models are suitable for analyzing the 
intensive margin job creation performance of firms located in Central and Eastern Europe. In line with the large literature on firm growth, we identify firm size, firm age, firm productivity and foreign ownership as robust determinants of the differences in the intensive margin job creation performance across firms. Moreover, industry-specific characteristics such as institutional barriers are significant determinants for the creation of productive jobs within existing firms ${ }^{23}$.

\section{Conclusions}

Our analysis of the determinants of intensive margin firm growth in CEE economies highlights several important firm-specific, sectorial and institutional factors that explain the observed differences in employment growth across existing enterprises in the region. During the boom years prior to the global financial crisis, traditional industries such as agriculture and fishing, mining, construction and manufacturing were crucial for the intensive margin net creation of jobs in CEE economies. In contrast, while the number of existing firms in the services sector was large, their role in creating jobs was not outstanding. At the firm level, small and younger surviving (including start-ups) were the most important contributors to job creation in CEE countries. In addition, the results demonstrate that firm productivity and foreign ownership went hand in hand with the creation of new jobs among the surveyed firms. Overall, the empirical results confirm that, in qualitative terms, the analyzed firm characteristics (such as size, age, TFP, foreign ownership, sectorial affiliation) affect intensive margin job creation both during recessions and economic recoveries. They indicate that more productive firms tend to be less vulnerable to economic downturns. Accordingly, any type of activities that increase productivity can be expected to reduce the overall exposure of CEE economies to recessions and, therefore, should allow existing firms to compete more successfully with international competitors.

The institutional business environment appears as a crucial correlate of employment growth among existing firms, a finding which is also confirmed for the share of highgrowth surveyed firms, which disproportionately accounted for the intensive margin creation of new jobs in CEE economies prior to the crisis. More specifically, based on quantile regressions the fastest growing continuing CEE firms are estimated to be most negatively affected by a poor business environment. Our empirical results point to the key role of improving the quality of the overall business environment for job creation in the CEE region. The empirical evidence suggests that improving the business climate, strengthening labor and regulatory practices, modernizing institutions, and deepening access to financial advances job creation should lead to leveling the playing field for all firms, boost overall productivity and, thus, contribute to the creation of new jobs at the intensive margin. Given the importance of the business environment for FDI inflows, reducing business restrictions should in addition increase medium-run and longrun productivity and overall competitiveness and indirectly contribute to job creation. As highlighted in Arias et al. (2013), a sound business environment, however, seems to be a necessary but not sufficient condition for sustained job creation.

\section{Endnotes}

${ }^{1}$ Throughout the study, the term CEE countries refers to the group of eleven countries which used to be centrally planned economies and are part of the EU as of 2013: 
Bulgaria, Croatia, the Czech Republic, Estonia, Hungary, Latvia, Lithuania, Poland, Romania, the Slovak Republic, and Slovenia.

${ }^{2}$ The number of employment growth observations by country available by country is given by the following figures. Bulgaria: 158,061, Czech Republic: 214,062, Estonia: 172,940, Croatia: 224,251, Hungary: 33,570, Lithuania: 26,443, Latvia: 29,531, Poland: 42,419, Romania: 1,606,639, Slovenia: 52,054, Slovak Republic: 30,167.

${ }^{3}$ A detailed data description for the Amadeus database is provided in Udomsaph (2013).

${ }^{4}$ Figure 1 was constructed using information for all countries in the sample with the exception of Hungary, where the number of active firms in 2002 is too small to make reasonable comparisons. For some countries, the number of active firms in 2002 is relatively small and, therefore, this figure cannot be easily compared to aggregated developments as documented in data provided by Eurostat. This figure only aims at illustrating the developments within our sample of firms.

${ }^{5}$ The Doing Business ranking of countries calculated from the BEEPS data closely matches the ranking provided by the doing business indicators. Since 2012 the Doing Business indicators include an overall "ease of doing business" rank for all countries that are included in the database (see, e.g., World Bank 2012). Comparing the "ease of doing business" rank with the BEEPS based index it turns out that Romania is poorly ranked in both data sets. In a similar vein, the Baltic States are among the most business-friendly CEE economies in both sources. However, Lithuania forms a notable exception because it is highly ranked in the doing business indicators but among the group of more business-unfriendly economies when looking at the BEEPS data. The main reason for this is that the BEEPS data end in 2009 while the "ease of doing business" ranking is only available since 2012. When looking at the Doing Business indicators for Lithuania over time, it turns out that the business environment substantially improved since 2009.

${ }^{6}$ The coefficient for the number of observed years does not have a clear economic interpretation and, therefore, these estimates are not reported in our regressions explaining the average annual employment growth rate but are available from the authors upon request.

${ }^{7}$ The importance of firm size a predictor of job creation is debated extensively in the literature. Davidsson et al. (1998) and Neumark et al. (2011) show that small and medium-sized enterprises (SMEs) tend to be the most important contributors to net job creation. By contrast, Haltiwanger et al. (2013) highlight the important role of business start-ups and young firms for job creation in the USA. Huber et al. (2012) document that in Austria large firms (irrespective of their age) positively contribute to (net) job creation, while in small firms more jobs are destroyed than created.

${ }^{8}$ However, as stressed by Haltiwanger et al. (2013), disentangling the role of firm size vis-à-vis age requires more comprehensive data than available for this paper. In particular, census data would allow for the proper estimation of employment shares and hazard rates of non-surviving firms.

${ }^{9}$ The estimation results for models which include TFP as an additional control are based on a subset of eight economies. The calculation of TFP using the Levinsohn and Petrin (2003) approach requires data on value added (or sales), inputs (i.e., labor and capital) and intermediate inputs (such as material costs). Unfortunately, the data at hand do not contain such information for Croatia, Estonia and Lithuania, which are thus not included in the estimation sample for models with TFP as a covariate. 
${ }^{10}$ The reported industry effects from the regression analysis have to be interpreted relative to the omitted group of firms, which in our case refers to firms operating in other services industries.

${ }^{11}$ It is worth noting that this finding strictly applies to the surveyed surviving firms. If entry and exit dynamics systematically differ between traditional industries and services providers, this result might be reversed. For this reason, it would be crucial to reexamine the job creation analysis using census data that allow us to account for firm entry and exit.

${ }^{12}$ However, Haltiwanger et al. (2013) and Huber et al. (2012) also document that young firms exhibit an increased exit hazard. Accordingly, an overall assessment of the contribution of young firms to overall job creation would require census data that also contain information on market entry and exit.

${ }^{13}$ In fact, when replacing average firm-specific TFP by its initial value the corresponding marginal effect amounts to 1.4 percentage points.

${ }^{14}$ This finding is in line with the previous work on the impact of institutional barriers on firm growth which identified financial constraints as the most crucial obstacle to growth (see, e.g., Beck et al. 2005 and Ayyagari et al. 2008).

${ }^{15}$ In order to check the robustness of the results reported in Table 1 we also estimated alternative specifications where we additionally include a dummy variable taking on the value of one only for firms located in Bulgaria, Romania or Croatia and additionally interact this dummy with all institutional variables reported in columns (2) to (8). These three countries were the last to join the EU and, thus, might lack behind in terms of institutional compliance with EU rules. In these generalized specifications, the dummy variable for firms located in these three countries is statistically insignificant throughout. Focusing on the interaction of this dummy variable with the institutional barriers for doing business we only identify a significant and negative parameter estimate for financial barriers, indicating that financial restrictions affect firms located in these three countries most severely.

${ }^{16}$ This result is in contrast to recent empirical studies that find a negative relationship between TFP growth and employment growth over time (see, e.g., De Michelis et al. 2013). There are several reasons for this finding. First, the results presented here are based on firm-level econometric TFP estimates, whereas industry and country studies typically rely on TFP measures based on growth accounting (see, e.g., De Michelis et al. 2013). Accordingly, one avenue for future research could include a systematic comparison of micro- and macro-based TFP measures. Second, in contrast to De Michelis et al. (2013), the sample in this analysis covers only emerging markets.

${ }^{17}$ Some recent applications of quantile regression methods for analyzing firm growth include e.g., Coad and Rao (2008, 2010), Hölzl (2009), Goedhuys, M. and Sleuwaegen, L. (2010) and Reichstein et al. (2010).

${ }^{18}$ Due to the disruption created by the global financial crisis in the growth pattern of firms in the region, the 2002-2008 period appears more suited to understand the differential role of institutional barriers as a determinant of job creation across enterprises which is studied using the quantile regression exercise. We also performed similar regressions for the 2008-2009 period, but no systematic pattern in the differences across percentiles emerged. The results of this exercise are available from the authors upon request.

${ }^{19}$ The confidence intervals are computed using 100 bootstrap replications. 
${ }^{20}$ This finding is consistent with the recent literature on the role of high growth firms for job creation. Henrekson and Johansson (2010), for example, provide a meta-study on the impact of gazelles for overall job creation and confirm the view that this group of firms accounts for the vast majority of newly created firms.

${ }^{21}$ Given the non-linear functional form of the probit model, the marginal firm size and firm age effects are already firm-specific, making an interaction effect unnecessary.

${ }^{22}$ One could alternatively use the years 2003 to 2005 in order to investigate the relationship between firm and industry-specific characteristics and the probability to be a gazelle. In qualitative terms, and with regard to the specific barriers for doing business, we obtain similar results when construction gazelles based on the years 2003 to 2005. Institutional regulations and crime increase the likelihood of being a high-growth firm, while limited access to finance and labor market regulations are harmful for gazelles. With regard to the overall level of institutional barriers for doing business, taxation and crime, the estimated marginal effects deviate from the ones for 2005 to 2008, indicating that the effect of institutional barriers might also change over time. The full set of results including the other firm and industry-specific controls are available from the authors upon request.

${ }^{23}$ One important drawback of this analysis, however, is related to the quality of the data at hand. A comprehensive analysis of the key firm and industry-specific determinants of job creation would require high-quality data on firm entry and exit as typically included in census data which are year unfortunately not publicly available.

\section{Additional file}

Additional file 1: Construction of institutional business barriers index.

Competing interests

The IZA Journal of European Labor Studies is committed to the IZA Guiding Principles of Research Integrity. The authors declare that they have observed these principles.

\section{Acknowledgements}

We would like to thank Martin Kahanec, two anonymous referees, Omar Arias, Alex Coad, Xavier Devictor, Doerte Doemeland, Hongjoo J. Hahm, Satu Kahkonen, Ismail Radwan, Carolina Sanchez-Paramo, Erwin H. R. Tiongson, and Charles Udomsaph for very helpful comments on earlier drafts of this paper. An earlier version of parts of this work appeared in the EU11 Regular Economic Report issue 27 (June), World Bank 2013 and was published as Policy Research Working Paper 6533 by The World Bank (Oberhofer, H. and Vincelette, G. A, (2013) Determinants of job creation in eleven new EU member states - evidence from firm level data," Policy Research Working Paper Series 6533, World Bank). Responsible editor: Martin Kahanec

\section{Author details \\ ${ }^{1}$ Vienna University of Economics and Business (WU), Vienna, Austria. ${ }^{2}$ International Institute for Applied Systems Analysis (IIASA), Laxenburg, Austria. ${ }^{3}$ Wittgenstein Centre for Demography and Global Human Capital (WIC), Vienna, Austria. ${ }^{4}$ Austrian Institute of Economic Analysis (WIFO), Vienna, Austria. ${ }^{5}$ University of Salzburg, Salzburg, Austria. ${ }^{6}$ Austrian Center for Labor Economics and the Analysis of the Welfare State, Linz, Austria. ${ }^{7}$ The World Bank, Poverty Reduction and Economic Management Department, Europe and Central Asia Region, Washington, DC, USA.}

Received: 3 September 2013 Accepted: 2 January 2014

Published: 07 Feb 2014

\section{References}

Arias OS, Sánchez-Páramo C, Dávalos ME, Santos I, Tiongson ER, Gruen C, de Andrade Falcão N, Saiovici G, Cancho CA (2013) Back to work: growing with jobs in Europe and Central Asia. World Bank, Washington D.C

Ayyagari M, Demirgüç-Kunt A, Maksimovic V (2008) How important are financing constraints? The role of ginance in the business environment. World Bank Econ Rev 22:483-516

Bartus T (2005) Estimation of marginal effects using margeff. Stata Journal 5:309-329.

Beck T, Demirgüç-Kunt A, Maksimovic V (2005) Financial and legal constraints to growth: does firm size matter? J Finance 60:137-177

Bevan AA, Estrin S (2004) The determinants of foreign direct investment into European transition economies. J Comp Econ 32:775-787 
Bilsen V, Konings J (1998) Job creation, job destruction, and growth of newly established, privatized, and state-owned enterprises in transition economies: survey evidence from Bulgaria, Hungary, and Romania. J Comp Econ 26:429-445

Coad A (2009) The growth of firms: a survey of theories and empirical evidence. Edward Elgar, Cheltenham, UK and Northampton, MA

Coad A, Hölzl W (2012) Firm growth: empirical analysis. In: Dietrich M, Krafft J (eds) Handbook on the economics and theory of the firm. Edward Elgar, Cheltenham, UK and Northampton, MA

Coad A, Rao R (2008) Innovation and firm growth in high tech sectors: a quantile regression approach. Res Policy 37:633-648

Coad A, Rao R (2010) Firm growth and R\&D expenditure. Econ Innov New Technol 19:127-145

Crespo Cuaresma J, Oberhofer H, Smits K, Vincelette GA (2012) Drivers of convergence in eleven eastern European countries. World Bank Policy Research Working Paper 6185. World Bank

Davidsson P, Lindmark P, Olofsson C (1998) The extent of overestimation of small firm job creation: an empirical examination of the regression bias. Small Business Econ 11:87-100

De Michelis A, Estevao M, Wilson BA (2013) Productivity or employment: is it a choice? Int Product Monitor 25:41-60

Eurostat (2013) Real GDP growth rate. http://epp.eurostat.ec.europa.eu/tgm/table.do? tab=table\&init=1\&plugin=1\&language=en\&pcode=tec00115. Accessed 7. November 2013

Fabry N, Zeghni S (2006) How former communist countries of Europe may attract inward foreign direct investment? A matter of institutions. Communist Post-Communist Stud 39:201-219

Geroski PA (2005) Understanding the implications of empirical work on corporate growth rates. Manag Dec Econ 26:129-138

Goedhuys M, Sleuwaegen L (2010) High-growth entrepreneurial firms in Africa: a quantile regression approach. Small Bus Econ 34:31-51

Hake M (2009) Firm growth and ownership change in CEE countries. Mimeo

Haltiwanger J, Jarmin RS, Miranda J (2013) Who creates jobs? Small vs. large vs. young. Rev Econ Stat 95:347-361

Harding T, Javorcik BS (2011) Roll out the red carpet and they will come: investment promotion and FDI inflows. Econ J 121:1445-1476

Hart PE (2000) Theories of firms' growth and the generation of jobs. Rev Indust Org 17:229-248

Henrekson M, Johansson D (2009) Competencies and institutions fostering high-growth firms. Foundations Trends in Entrepreneurship 5:1-80

Henrekson M, Johansson D (2010) Gazelles as job creators: a survey and interpretation of the evidence. Small Bus Econ 35:227-244

Henrekson M, Johansson D (2011) Firm growth, institutions and structural transformation. In: Fritsch M (ed) Handbook of research and entrepeneurship and regional development. Edward Elgar Cheltenham, UK and Northampton, MA

Hölzl W (2009) Is the R\&D behaviour of fast-growing SMEs different? Evidence from CIS III data for 16 countries. Small Bus Econ 33:59-75

Huber P, Oberhofer H, Pfaffermayr M (2012) Who creates jobs? Estimating job creation rates at the firm level. WIFO Working Papers No. 435. Austrian Institute of Economics Research

Jimenez A, Fuente JM, Duran JJ (2011) Is there an East-west structure in the location of FDI in Europe? The role of institutions and political risk. Res Econ Bus Central East Eur 3:5-24

Klapper LF, Sarria-Allende V, Sulla V (2002) Small- and medium-size enterprise financing in Eastern Europe. World Bank Policy Research Working Paper 2933. World Bank

Koenker R, Bassett G (1978) Regression quantiles. Econometrica 46:33-50

Koenker R, Hallock KF (2001) Quantile regression. J Econ Perspect 15:143-156

Konings J (1997) Firm growth and ownership in transition countries. Econ Letters 55:413-418

Konings J, Ana Xavier A (2002) Firm growth and survival in a transition country: micro evidence from Slovenia. LICOS discussion papers 11402. LICOS - Centre for Institutions and Economic Performance, KU Leuven

Levinsohn J, Petrin A (2003) Estimating production functions using inputs to control for unobservables. Rev Econ Stud 243:317-342

Neumark D, Wall B, Zhang J (2011) Do small businesses create more jobs? New evidence for the United States from the national establishment time series. Rev Econ Stat 93:16-29

Oberhofer H (2012) Firm growth, European industry dynamics and domestic business cycles. Scottish J Politic Econ 59:316-337

Oberhofer H (2013) Employment effects of acquisitions: evidence from acquired European firms. Rev Ind Org 42:345-363

Oberhofer H, Pfaffermayr M (2013) Firm growth in multinational corporate groups. Empiric Econ 44:1435-1453

OECD (2009) Measuring entrepreneurship: a collection of indicators. OECD, Paris

Peng M, Heath PS (1996) The growth of the firm in planned economies in transition: Institutions, organizations, and strategic shoice. Acad Manag Rev 21:492-528

Pilat P, Cimper A, Olsen K, Webb C (2006) The changing nature of manufacturing in OECD economies. STI Working Paper 2006/9. OECD

Pournarakis M, Varsakelis NC (2004) Institutions, internationalization and FDI: the case of economies in transition. Transnat Corp 13:77-94

Raiser M, Gill IS (2012) Golden growth: Restoring the lustre of the European economic model. World Bank, Washington, DC

Reichstein T, Dahl MS, Ebersberger B, Jensen MB (2010) The devil dwells in the tails A quantile regression approach to firm growth. J Evolut Econ 20:219-231

Studena I (2004) Firm growth in advanced stages of economic transition: Evidence from Slovak industry. Czech J Econ Finance 54:436-455

Tintin C (2013) The determinants of foreign direct investment inflows in the Central and Eastern European Countries: The importance of institutions. Communist Post-Communist Stud 46:287-298

Udomsaph C (2013) Assessment of Bureau van Dijk's Amadeus database for analytical work in ECA. Mimeo, World Bank World Bank (2012) Doing business 2012: doing business in a more transparent world. World Bank, Washington D.C

10.1186/2193-9012-3-3

Cite this article as: Cuaresma et al.: Institutional barriers and job creation in Central and Eastern Europe. IZA Journal of European Labor Studies 2014, 3:3 